\title{
Magmatic and tectonic history of Jurassic ophiolites and associated granitoids from the South Apuseni Mountains (Romania)
}

\section{Journal Article}

Author(s):

Gallhofer, Daniela; von Quadt, Albrecht; Schmid, Stefan M.; Guillong, Marcel (D); Peytcheva, Irena; Seghedi, Ioan

Publication date:

2017-06

Permanent link:

https://doi.org/10.3929/ethz-b-000122739

Rights / license:

In Copyright - Non-Commercial Use Permitted

Originally published in:

Swiss Journal of Geosciences 110(2), https://doi.org/10.1007/s00015-016-0231-6

\section{Funding acknowledgement:}

146681 - Fluid chemistry and fluid-rock interaction of Alpine veins, Central Alps (SNF)

146651 - Mineral resources: Physical dynamics driving chemical enrichment of rare metals (SNF) 
This is the Green Open Access version of: Gallhofer, D., von Quadt, A., Schmid, S.M., Guillong, M., Peytcheva, I. and Seghedi, I. (2017). Swiss Journal of Geosciences, vol. 110, p. 699-719.

Original publication see https://doi.org/10.1007/s00015-016-0231-6

\title{
Magmatic and tectonic history of Jurassic ophiolites and associated granitoids from the South Apuseni Mountains (Romania)
}

\author{
Daniela Gallhofer ${ }^{1 *}$, Albrecht von Quadt ${ }^{1}$, Stefan M. Schmid ${ }^{2}$,Marcel Guillong ${ }^{1}$, Irena \\ Peytcheva $^{1,3}$, Ioan Seghedi ${ }^{4}$
}

\author{
1'Institute of Geochemistry and Petrology, ETH Zürich, Clausiusstrasse 25, 8092 Zürich, \\ Switzerland \\ 2Institute of Geophysics, ETH Zürich, Sonneggstrasse 5, 8092 Zürich, Switzerland \\ ${ }^{3}$ Department of Geochemistry and Petrology, Bulgarian Academy of Sciences, Acad. G. Bonchev- \\ Str. 24, 1113 Sofia, Bulgaria \\ ${ }^{4}$ Institute of Geodynamics, Romanian Academy, 19-21, Jean-Luis Calderon str., Bucharest \\ 020032, Romania
}

Corresponding author: daniela.gallhofer@erdw.ethz.ch

Keywords: East Vardar ophiolites, U-Pb zircon dating, LA-ICP-MS, radiogenic Sr-Nd isotopes, obduction onto Dacia Mega-Unit, island arc

\begin{abstract}
The Jurassic ophiolites in the South Apuseni Mountains represent remnants of the Neotethys Ocean and belong to the East Vardar ophiolites that contain ophiolite fragments as well as granitoids and volcanics with island-arc affinity. New U-Pb zircon ages, and $\mathrm{Sr}$ and $\mathrm{Nd}$ isotope ratios give insights into their tectono-magmatic history. The ophiolite lithologies show tholeiitic MOR-type affinities, but are occasionally slightly enriched in Th and $U$, and depleted in $\mathrm{Nb}$, which indicates that they probably formed in a marginal or back-arc basin. These ophiolites are associated with calc-alkaline granitoids and volcanics, which show trace element signatures characteristic for subduction-enrichment (high LILE, low HFSE). Low ${ }^{87} \mathrm{Sr} /{ }^{86} \mathrm{Sr}$ ratios $(0.703836-$ $0.704550)$ and high ${ }^{143} \mathrm{Nd} /{ }^{144} \mathrm{Nd}$ ratios (0.512599-0.512616) of the calc-alkaline series overlap with the ratios measured in the ophiolitic rocks (0.703863-0.704303 and 0.512496-0.512673), and hence show no contamination with continental crust. This excludes a collisional to postcollisional origin of the granitoids and is consistent with the previously proposed intra-oceanic island arc setting. The new U-Pb ages of the ophiolite lithologies (158.9-155.9 Ma, Oxfordian to Early Kimmeridgian) and granitoids (158.6-152.9 Ma, latest Oxfordian to Late Kimmeridgian) indicate that the two distinct magmatic series evolved within a narrow time range. It is proposed that the ophiolites and island arc granitoids formed above a long-lived NE-dipping subduction zone. A sudden flip in subduction polarity led to collision between island arc and continental margin, immediately followed by obduction of the ophiolites and granitoids on top of the continental margin of the Dacia Mega-Unit. Since the granitoids lack crustal input, they must have intruded the Apuseni ophiolites before both magmatic sequences were obducted onto the continental margin. The age of the youngest granitoid ( $\sim 153 \mathrm{Ma}$, Late Kimmeridgian) yields an estimate for the maximum age of emplacement of the South Apuseni ophiolites and associated granitoids onto the Dacia Mega-Unit.
\end{abstract}

\section{Introduction}

Understanding opening and closure of the Neotethys Ocean is essential for unraveling the Mesozoic tectonic evolution of the Carpathian-Dinaride-Balkan orogen. The northern branch of Neotethys opened in Triassic times and formerly divided the European continental margin from 
the Adriatic microplate that only temporarily was attached to the African plate (e.g. Schmid et al. 2008; Handy et al. 2010). Convergence between the European and the Adriatic microplate, which presently is still going on, led to closure of the Neotethys Ocean during several stages in the Mesozoic. Remnants of the Neotethys Ocean are therefore preserved in different tectonic positions, which previously led workers to distinguish several ocean basins in the CarpathianDinaride-Balkan orogen (e.g. Csontos and Vörös 2004; Robertson et al. 2009). Here, we adopt the "one-ocean" concept that was first formulated by Bernoulli and Laubscher (1972) and more recently revived by others (e.g. Bortolotti and Principi 2005; Schmid et al. 2008).

According to the "one-ocean" concept, the three different types of ophiolitic units occurring between the Carpathian-Balkan and Dinaride orogens are sourced in the same long-lived Neotethys Ocean. The Sava zone (sensu Schmid et al. 2008) is the only real suture zone and is related to the final closure of the Neotethys Ocean in this region at the end of the Cretaceous (Karamata 2006; Ustaszewski et al. 2010) (Fig. 1). The large sheets of ophiolites preserved to the east and west of this suture zone (the East Vardar ophiolites and West Vardar ophiolites sensu Schmid et al. 2008, Fig. 1) lie on top of continental units. Although still disputed, many authors agree now that the East and West Vardar ophiolites were obducted onto the continental units during Late Jurassic to Early Cretaceous times (Pamić et al. 2002; Karamata 2006; Schmid et al. 2008; Hoeck et al. 2009; Ionescu et al. 2009; Kounov and Schmid 2013).

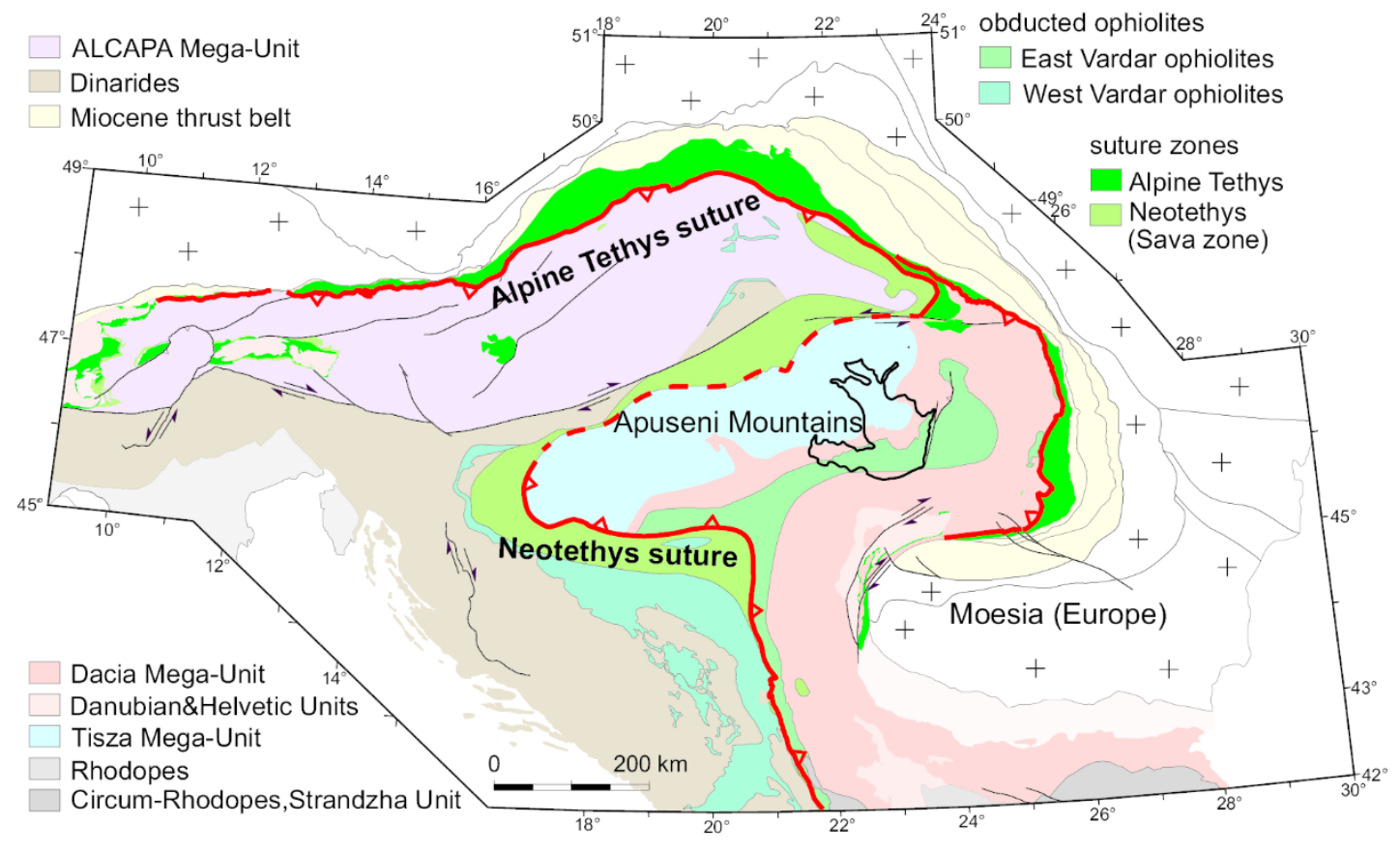

Figure 1: Geological map of the Alpine-Carpathian-Dinaride orogen (modified from Schmid et al. 2008). The red lines denote the suture zones of the Alpine Tethys and Neotethys Oceans. The black line surrounds the outcropping preCenozoic areas of the Apuseni Mountains.

The obducted East Vardar ophiolites form only a narrow strip running east of, and parallel to, the Sava suture zone through eastern Serbia, Macedonia (former Yugoslav Republic of Macedonia, FYROM) into Greece where these ophiolites form part of the Circum-Rhodope belt. East Vardar ophiolites crop out in a larger area in the South Apuseni nappes of the Apuseni Mountains of Romania (also referred to as Mureș ophiolites) and in the subsurface of the Transylvanian basin (Fig. 1). These South Apuseni-Transylvanian ophiolite nappes overlie the continental Dacia Mega-Unit (Kounov and Schmid 2013) (Fig. 1) and are believed to consist of Middle Jurassic ophiolites which comprise mid ocean ridge (MOR)- or back arc (BA)-type basalts and gabbros, and presumably Late Jurassic granitoids and their volcanic equivalents with an island arc affinity (Savu et al. 1981; Bortolotti et al. 2002; Nicolae and Saccani 2003; Bortolotti et al. 2004). So far the ages of the magmatic sequences and the timing of obduction are only loosely 
constrained based on biostratigraphic ages of associated sediments, unreliable K-Ar ages, and scarce Re-Os ages of molybdenite veins occurring in the granitoids (Nicolae et al. 1992; Bortolotti et al. 2004; Zimmerman et al. 2008). Hence, more reliable geochronological constraints are necessary to refine the magmatic and tectonic evolution of ophiolites and associated granitoids and the timing of obduction of the South Apuseni-Transylvanian nappes.

So far the distinction between Mid Ocean Ridge (MOR) or Backarc (BA) basalts and gabbros (thereafter referred to as "ophiolites") and island arc series (thereafter referred to as "granitoids", which is loosely applied to a range of intermediate to felsic plutonic rocks and equivalent subvolcanics and volcanics) in the South Apuseni nappes is based on detailed petrographic observations and geochemistry (Nicolae and Saccani 2003; Bortolotti et al. 2004). However, radiogenic isotope ratios, which would give additional insights into the source of the two magmatic series, are not available for the South Apuseni nappes. Radiogenic isotope ratios have been used to detect crustal assimilation in granitoids from other parts of the East Vardar ophiolites, and led to a fundamentally different interpretation of the tectonic setting of some of the alleged island arc granitoids (Šarić et al. 2009). Šarić et al. (2009) attributed high ${ }^{87} \mathrm{Sr} /{ }^{86} \mathrm{Sr}$ and low ${ }^{143} \mathrm{Nd} /{ }^{144} \mathrm{Nd}$ ratios found in some granitoids to assimilation of continental crust, which supposedly occurred in a post-collisional setting rather than in an intra-oceanic island arc. Hence, $\mathrm{Sr}$ and $\mathrm{Nd}$ isotope analyses of the granitoids in the Apuseni Mountains are useful in fingerprinting different geochemical reservoirs, potentially located in the mantle or the continental crust, and will contribute to identifying the tectonic setting.

Here, we present new U-Pb zircon ages for the Apuseni ophiolites and associated granitoids. We obtained whole rock major and trace element data, and $\mathrm{Sr}$ and $\mathrm{Nd}$ isotope ratios of the same samples and combine our geochemical data with a previously published dataset (Bortolotti et al. 2004). We discuss the tectonic significance of the geochemical data and the new $\mathrm{U}-\mathrm{Pb}$ ages, and refine existing geodynamic models (Bortolotti et al. 2002; Ionescu et al. 2009; Kounov and Schmid 2013) regarding the obduction of the South Apuseni-Transylvanian nappes.

\section{Geological Setting of the Apuseni Mountains}

The Apuseni Mountains form a mountainous area inside the arcuate Carpathian orogen. They are bordered to the east by the Late Cretaceous to Cenozoic Transylvanian basin and to the west by the Cenozoic Pannonian basin (Fig. 1). Geotectonically, the Apuseni Mountains are located at the contact between the continental Tisza and Dacia Mega-Units. At the southern and eastern rim of the Apuseni Mountains the South Apuseni nappes comprising the East Vardar ophiolites overlie the Dacia Mega-Unit (e.g. Csontos and Vörös 2004; Schmid et al. 2008). All tectonic units are unconformably covered by Late Cretaceous post-tectonic sediments (Gosau-type sediments; Schuller et al. 2009), and intruded by Late Cretaceous and Miocene calc-alkaline igneous suites (e.g. Berza et al. 1998; Rosu et al. 2004; Seghedi et al. 2004) (Fig. 2).

The continental Tisza and Dacia Mega-Units comprise poly-phase (Variscan and Alpine) metamorphic basement and sedimentary cover nappes, which split off from Europe during the opening of the Alpine Tethys and hence partly show European faunal affinity (Csontos and Vörös 2004; Haas and Pero 2004; Iancu et al. 2005). The lowermost Bihor and Codru nappe systems in the NW are ascribed to the Tisza Mega-Unit (e.g. Csontos and Vörös 2004) and consist of partly Neoproterozoic basement intruded by Paleozoic granites, and Late Paleozoic to Mesozoic cover sediments (Pana et al. 2002; Balintoni et al. 2009; Balintoni et al. 2010). The uppermost Biharia nappe system, previously regarded as an integral part of the Tisza Mega-Unit (e.g. Csontos and Vörös 2004), is now assigned to the Dacia Mega-Unit (Schmid et al. 2008). This is, for example, based on the observation that the East Vardar ophiolites south of the Apuseni Mountains always overlie nappes of the Dacia Mega-Unit (see Schmid et al. 2008 for further details). The Biharia nappe system is composed of polymetamorphic Variscan basement (Dallmeyer et al. 1999) and post-Variscan to Mesozoic metasediments (Csontos and Vörös 2004). Parts of the Biharia nappe were buried and metamorphosed during the Early Cretaceous (e.g. Dallmeyer et al. 1999). 


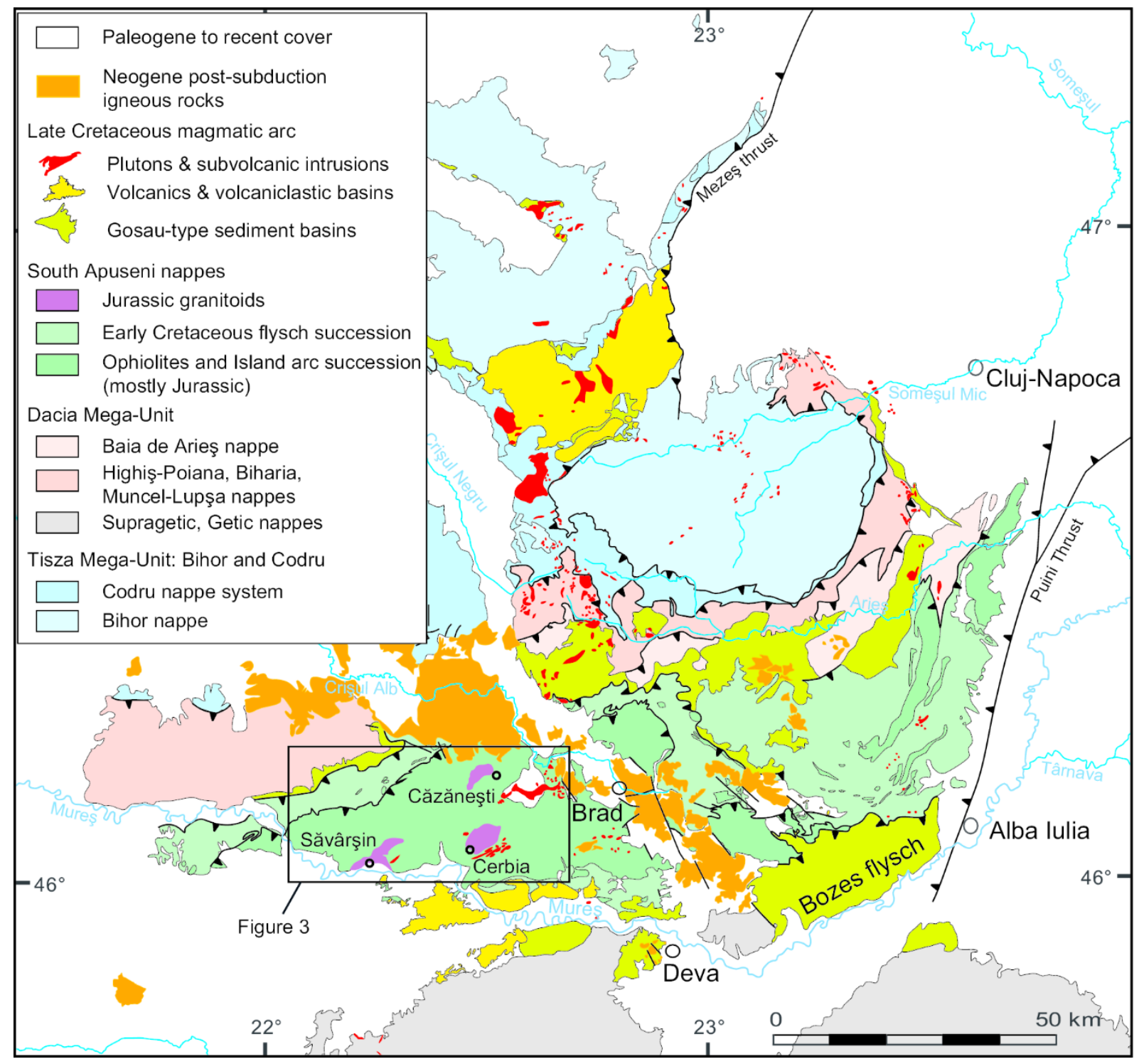

Figure 2: Geological map of the Apuseni Mountains, redrawn from published geological maps of the Geological Institute of Romania (scale 1:200000), and modified after Balintoni (1994) and Kounov and Schmid (2013).

The East Vardar ophiolites, known as the South Apuseni nappes in the Apuseni Mountains, overlie the Biharia nappe system (e.g. Savu 1996; Zacher and Lupu 1999; Bortolotti et al. 2004; Schmid et al. 2008; Kounov and Schmid 2013). In this contribution we use the term South Apuseni ophiolitic unit for a composite unit that is subdivided into presumably Middle Jurassic MOR- or BA-type basalts and gabbros (ophiolites) and Late Jurassic granitoids, and their subvolcanic and volcanic equivalents (granitoids, sensu lato) that probably originated in an island arc setting (Savu et al. 1981; Bortolotti et al. 2002; Nicolae and Saccani 2003; Bortolotti et al. 2004). We use the time scale of Cohen et al. (2013) for correlation of radiometric and stratigraphic data.

In the Mureș valley, the ophiolites are strongly dismembered into several tectonic slices, and according to Bortolotti et al. (2002) the MOR-type ophiolite sequence is $\sim 2000 \mathrm{~m}$ thick. From bottom to top, the sequence comprises an intrusive section of layered and isotropic gabbros and rare ultramafic cumulates, which are followed upwards by a sheeted dyke complex, and an extensive volcanic sequence that includes flows and pillow-lava basalts (Bortolotti et al. 2002). The age of the ophiolites is poorly constrained by a wide spread of K-Ar whole rock ages $(\sim 168$ $139 \mathrm{Ma}$ ) (Nicolae et al. 1992) and Callovian to Oxfordian ( 166-157 Ma) radiolarites deposited on top of the ophiolites (Lupu et al. 1995). 
The ophiolites are intruded by granitoid bodies (mainly granites and granodiorites, subordinately diorites) and overlain by massive lava flows with island arc affinities ranging in composition from basalts to rhyolites (Nicolae and Saccani 2003; Bortolotti et al. 2004). Two ReOs ages (159.1 \pm 0.5 and $159.8 \pm 0.7 \mathrm{Ma}$ ) (Zimmerman et al. 2008) have been obtained from molybdenite associated with granitoids in the Mureş valley. According to published geological maps (1:50000) of the Geological Institute of Romania, the volcanic cover with island arc affinities is supposedly older than the granitoids. Late Jurassic (Kimmeridgian-Tithonian, 157$145 \mathrm{Ma}$ ) to Early Cretaceous shallow water limestones (Bortolotti et al. 2002; Şerban et al. 2004) and Early Cretaceous flysch overlie the ophiolites and granitoids in the Mureş valley.

The Alpine tectonic evolution started in the Late Jurassic with the tectonic emplacement of the South Apuseni ophiolitic unit onto the continental Biharia nappe system (Kounov and Schmid 2013). Late Jurassic to Early Cretaceous shallow water carbonates unconformably overlie the South Apuseni ophiolitic unit as well as the continental basement units in the Trascău mountains (east of the study area) (Bucur and Săsăran 2005), which implies that obduction must have occurred before deposition of these carbonates, presumably in the Late Oxfordian (Kounov and Schmid 2013). According to some authors (e.g. Schmid et al. 2008; Kounov and Schmid 2013) Late Jurassic obduction was triggered by the closure of the Eastern Vardar branch of Neotethys, which led to the collision of the continental Tisza and Dacia Mega-Units in the Apuseni Mountains in the Early Cretaceous and the formation of an ophiolitic suture between these two Mega-Units. Others (e.g. Csontos and Vörös 2004; Reiser et al. 2016) regard the Tisza and Dacia Mega-Units as a single continental entity at the time of obduction. In a later, "intra-Turonian" phase (Săndulescu 1984, 1994) that formed the present-day nappe stack in the Apuseni Mountains, the Dacia Mega-Unit and overlying ophiolitic unit were thrust over the Tisza MegaUnit. The entire Apuseni nappe stack underwent substantial clockwise rotation $\left(\sim 90^{\circ}\right)$ in the Cenozoic (Pătraşcu et al. 1990; Pătraşcu et al. 1994; Márton et al. 2007), when it moved around the Moesian platform and invaded the still open Carpathian embayment (e.g. Fügenschuh and Schmid 2005; Ustaszewski et al. 2008).

\section{Methods}

Fused glass beads of rock powder mixed with Lithium-Tetraborate (1:5) were analysed for major element oxides by x-ray fluorescence (XRF) using an Axios PANalytical WD-XRF spectrometer at ETH Zürich. Trace elements and rare earth elements were determined on freshly broken surfaces of the same glass beads by laser-ablation inductively-coupled-plasma mass spectrometry (LA-ICP-MS). Strontium and Neodymium isotopes were analysed on 50 to 70 mg whole rock powder digested in $\mathrm{HF}$ and $\mathrm{HNO}_{3}$. Sr and $\mathrm{Nd}$ were subsequently separated by ionexchange chromatography in columns with SrSpec, TRUSpec and LnSpec Eichrom resins (Pin et al. 1994). Strontium was loaded onto outgassed Re single filaments with $\mathrm{HNO}_{3}$ and $\mathrm{Ta}$ emitter, whereas the $\mathrm{Nd}$ fraction was loaded onto double filaments with $2 \mathrm{~N} \mathrm{HCl}$. Both were analysed with a Thermo Scientific TritonPlus mass spectrometer at ETH Zürich. Repeated measurements of NBS 987 and JNd-i yielded a mean ${ }^{87} \mathrm{Sr} /{ }^{86} \mathrm{Sr}$ ratio of $0.710234 \pm 0.000004$ and a mean ${ }^{143} \mathrm{Nd} /{ }^{144} \mathrm{Nd}$ ratio of $0.512100 \pm 0.000003\left(2 \sigma_{\mathrm{m}}\right)$, respectively.

Following standard zircon separation, the zircons were pre-treated by chemical abrasion to remove those domains of zircon grains that have lost $\mathrm{Pb}$ (Mattinson 2005). The abraded zircons were mounted in epoxy resin and polished to expose the grain centers. Cathodoluminescence (CL) pictures were taken to resolve inherited cores and freshly grown rims of single zircon grains using a FEI Quanta 200 FEG at the Scientific Center for Optical and Electron Microscopy at ETH Zürich [www.scopem.ethz.ch]. In-situ laser-ablation inductively-coupled-plasma mass spectrometry (LA-ICP-MS) was performed with an Element-XR SF-ICP-MS (Thermo Fisher, Bremen, Germany) coupled to an $193 \mathrm{~nm}$ Excimer laser (Resonetics Resolution S155-LR). The Excimer laser was operated at $5 \mathrm{~Hz}$ with a spot size of $30 \mu \mathrm{m}$ (detailed setup in von Quadt et al. 2014). Blocks of several 100 analyses were run including a minimum of 15 analyses of the primary standard zircon GJ-1. Secondary standard zircons Plesovice, 91500 and Temora were analysed for data quality control. No common lead correction was performed on the data 
acquired with this system owing to low count rates of $204 \mathrm{~Pb}$. The obtained raw data was imported into Iolite (Paton et al. 2010; Paton et al. 2011) and reduced and corrected for downhole fractionation using the VizualAge data reduction scheme (Petrus and Kamber 2012). The software Isoplot 3.75 (Ludwig 2012) was used to prepare Concordia diagrams and calculate weighted average ages (Online Resource 1). We report weighted average ${ }^{206} \mathrm{~Pb} /{ }^{238} \mathrm{U}$ ages and total uncertainty of the ages comprising internal and propagated external errors (Tab. 3). The total uncertainty of the ages is at $2 \sigma$ level and is calculated by adding the uncertainties of the decay constant, of the age of the primary standard, of the corrections and of the initial common $\mathrm{Pb}$ quadratically to the weighted mean error [total uncertainty= sqrt(weighted mean error $^{\wedge} 2+$ total external errors ${ }^{\wedge} 2$ )] (Gehrels et al. 2008). LA-ICP-MS single zircon dates for the Banat and Apuseni segments are reported in Online Resource 2.

\section{Results}

Our geochemical dataset of the Jurassic South Apuseni ophiolites and associated granitoids is supplemented with geochemical data previously published by Bortolotti et al. (2004) in order to show differences between the Jurassic MOR- or BA-type ophiolite lithologies and the granitoids and subvolcanic and volcanic equivalents with an island arc affinity. Additionally, we present $\mathrm{Sr}$ and $\mathrm{Nd}$ isotope ratios for the ophiolitic rocks and the granitoids. Mean ${ }^{206} \mathrm{~Pb} /{ }^{238} \mathrm{U}$ ages were obtained by in-situ LA-ICP-MS dating of zircons from the ophiolite lithologies and granitoids.

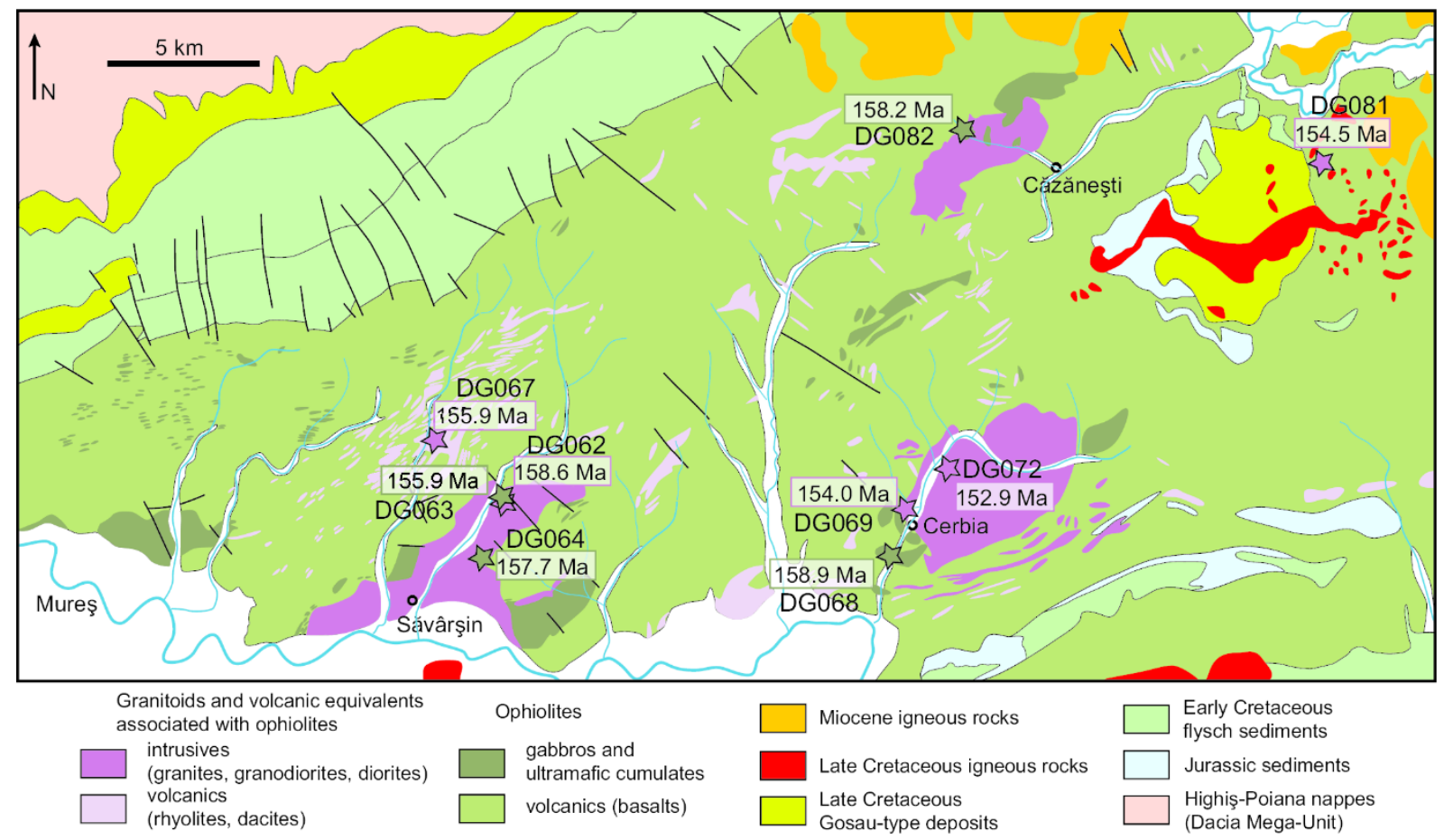

Figure 3: Geological map of the South Apuseni ophiolitic unit in the Mureş valley, redrawn from published geological maps of the Geological Institute of Romania (scale 1:50000) (Savu et al. 1979a, b, c; Lupu et al. 1986; Savu et al. 1991). Purple stars and numbers indicate sample location and mean ${ }^{206} \mathrm{~Pb} /{ }^{238} \mathrm{U}$ ages of granitoids, green stars and numbers indicate sample location and mean ${ }^{206} \mathrm{~Pb} /{ }^{238} \mathrm{U}$ ages of gabbros from the ophiolites.

\section{Sampling, Field Observations and Petrography}

For this study, the western occurrences of the South Apuseni ophiolites and granitoids in the Mureş valley were sampled (Figs. 2 and 3). In the South Apuseni ophiolites the intrusive section (Bortolotti et al. 2002, 2004) was sampled. This section contains layered and isotropic gabbros (samples DG064, DG068, DG082), occasionally also microgabbros do occur. Apart from one basalt with columnar jointing, the sheeted dykes, massive and pillow-lava basalts were not sampled due to the smaller chance of finding zircons in mafic volcanics. The gabbros have a coarse crystalline texture and consist of twinned plagioclase and interstitial to hypidiomorphic clinopyroxene, which is partially replaced by chlorite and opaque phases (Fig. 4a). Two dioritic 
samples (DG063, DG066) consist of plagioclase, chlorite and amphibole, which are probably both secondary phases replacing primary pyroxenes, and accessory apatite and opaques. There are three major granitoid bodies intruding the ophiolites, the Săvârşin (sample DG062, DG065), Cerbia (DG069, DG072) and Căzăneşti bodies (Fig. 3). They mainly consist of granites and granodiorites, and the marginal zones are sometimes made up of quartz-diorites. Additionally, felsic volcanics regarded to be equivalents of the granitoids occur west of the Săvârşin intrusive body on top of the ophiolites, and we sampled a dyke-like porphyritic rhyolite (DG067). A subvolcanic andesite (DG081) was sampled close to Birtin (WGS84 Decimal Degrees 46.15100 22.62997). The granites to granodiorites have equigranular to porphyritic textures and consist of plagioclase, which partly occurs as large phenocrysts, and alkali-feldspar and quartz, which frequently show granophyric intergrowths (Fig. 4b). Biotite and occasionally green amphibole are the dominant mafic phases and are partially replaced by secondary chlorite. Apatite and opaques are common accessory phases.
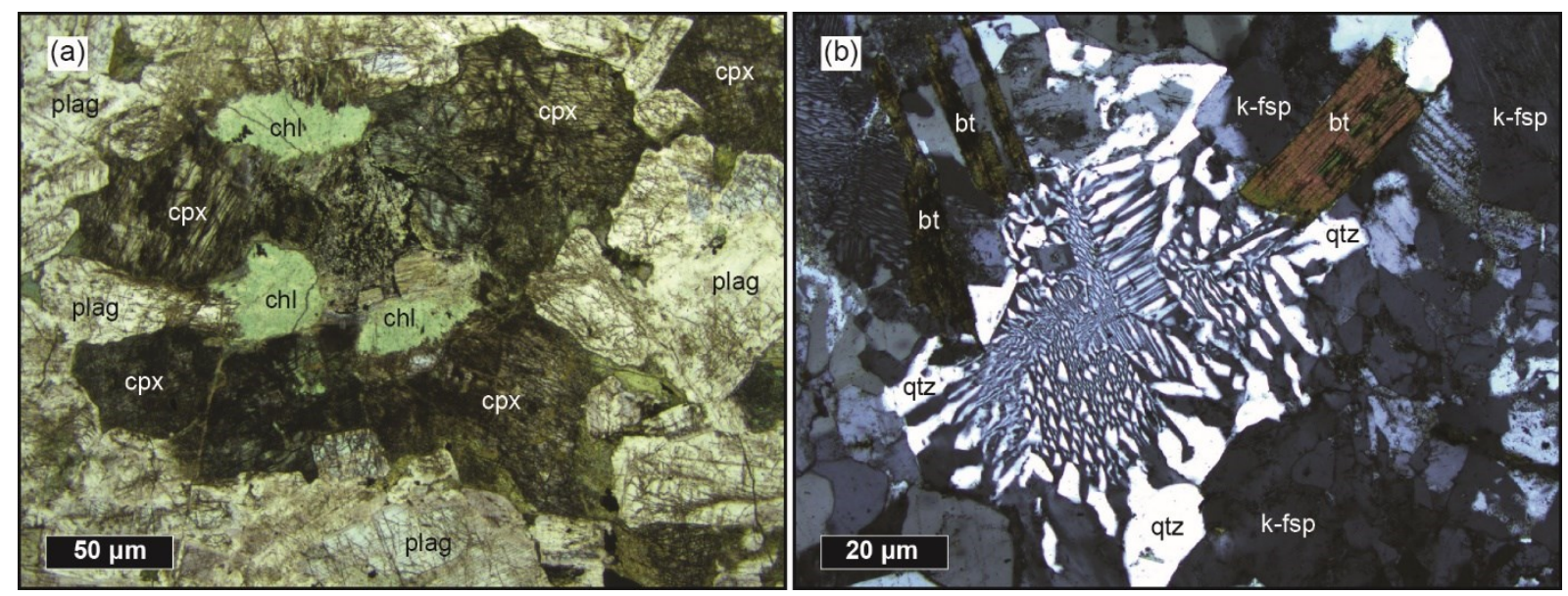

Figure 4: Textures of ophiolitic rocks and associated granitoids. (a) Coarse crystalline gabbro (DG064) consisting of plagioclase and clinopyroxene, which is partially replaced by chlorite. Photomicrograph was taken under plane polarized light. (b) Granite (DG072) showing granophyric intergrowth of K-feldspar and quartz. Photomicrograph was taken under crossed polarizers. bt: biotite, chl: chlorite, cpx: clinopyroxene, k-fsp: alkali-feldspar, plag: plagioclase, qtz: quartz.

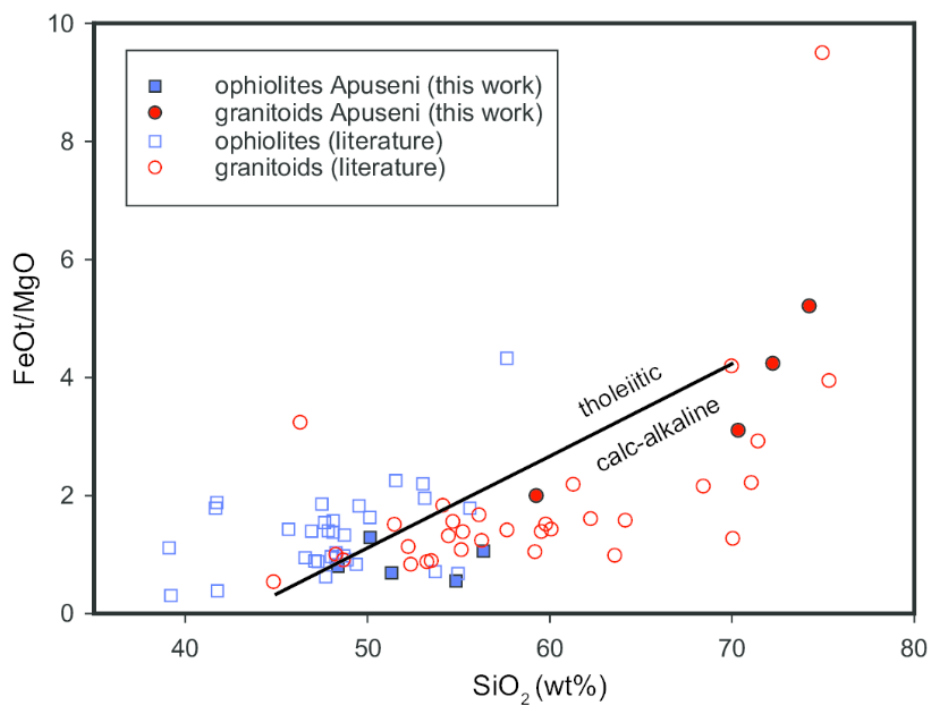

Figure 5: $\mathrm{FeOt} / \mathrm{MgO}$ versus $\mathrm{SiO}_{2}$ classification diagram after Miyashiro (1974). Apuseni ophiolite lithologies and associated granitoids are plotted for comparison (including data from Bortolotti et al. 2004). 


\section{Major and Trace Element Characteristics}

The major and trace element whole rock characteristics are reported in Table 1 and generally show differences between ophiolite lithologies and associated granitoids and igneous rocks with an island arc affinity. On Miyashiro's (1974) discrimination plot of $\mathrm{FeOt} / \mathrm{MgO}$ versus $\mathrm{SiO}_{2}$ the granitoids and their subvolcanic and volcanic equivalents plot in the calc-alkaline field, whereas most ophiolitic rocks plot in the tholeiitic field due to their higher FeOt contents (Fig. 5). In major element variation plots (Fig. 6), the granitoids and igneous rocks of the calc-alkaline series show a decrease of $\mathrm{MgO}, \mathrm{Al}_{2} \mathrm{O}_{3}$ and $\mathrm{CaO}$ with increasing $\mathrm{SiO}_{2} . \mathrm{Na}_{2} \mathrm{O}$ and $\mathrm{P}_{2} \mathrm{O}_{5}$ initially increase and then decrease with increasing $\mathrm{SiO}_{2}$, whereas $\mathrm{Al}_{2} \mathrm{O}_{3}$ is constant until $60 \mathrm{wt} \% \mathrm{SiO}_{2}$ and decreases at higher $\mathrm{SiO}_{2}$ contents. The ophiolite lithologies generally have lower $\mathrm{SiO}_{2}$ contents, lower $\mathrm{Al}_{2} \mathrm{O}_{3}$ and $\mathrm{K}_{2} \mathrm{O}$ contents, and higher $\mathrm{CaO}$ and $\mathrm{MgO}$ contents compared to the granitoids and their volcanic equivalents. $\mathrm{Na}_{2} \mathrm{O}$ and $\mathrm{P}_{2} \mathrm{O}_{5}$ contents increase with increasing $\mathrm{SiO}_{2}$ to partly higher values than observed in the granitoids and volcanic equivalents. The granitoids and igneous rocks of the calc-alkaline series and the tholeiitic ophiolitic rocks are clearly distinct in the $\mathrm{TiO}_{2}$ and $\mathrm{FeOt}$ versus Mg-number plots (Fig. 6). The ophiolitic rocks trend towards high $\mathrm{TiO}_{2}$ and $\mathrm{FeOt}$ contents with decreasing $\mathrm{Mg}$-number, whereas $\mathrm{TiO}_{2}$ and $\mathrm{FeOt}$ contents decrease with decreasing Mg-number in the calc-alkaline series.

Chondrite normalized rare earth element (REE) plots (Fig. 7a) show an elevation of light REE (LREE), relatively flat heavy REE and no or slightly negative Eu anomalies (Eu/Eu* $=0.6$ to 1.0) in the calc-alkaline granitoids. By contrast, the normalized patterns of rocks from the ophiolites are flat and LREE are slightly depleted or have the same abundance as HREE (Fig. 7b). In N-MORB (normal mid ocean ridge basalt) normalized trace element plots, the calc-alkaline series shows an enrichment in large ion lithophile elements (LILE, e.g. Ba, $\mathrm{K}, \mathrm{Pb}$ ) and depletions in high field strength elements (HFSE, e.g. Nb, Ta, Ti) (Fig. 7c). The ophiolitic rocks generally have lower trace element contents. Their LILE contents are generally low, but Th and $\mathrm{U}$ are slightly enriched, and the ophiolitic rocks lack a depletion in Ti (Fig. 7d).

\section{Sr and Nd isotopes}

The initial Sr and Nd isotope ratios of the Jurassic ophiolitic rocks and granitoids from the South Apuseni ophiolitic unit partly overlap (Tab. 2, Fig. 8). The granitoids have a range of age corrected ${ }^{87} \mathrm{Sr} /{ }^{86} \mathrm{Sr}$ ratios from 0.703836 to 0.704550 , and the ${ }^{143} \mathrm{Nd} /{ }^{144} \mathrm{Nd}$ ratios vary only little from $0.512599-0.512616$. The gabbros from the ophiolites have ${ }^{87} \mathrm{Sr} /{ }^{86} \mathrm{Sr}_{i}$ ratios $(0.703863$ 0.704303 ) similar to the granitoids, but their ${ }^{143} \mathrm{Nd} /{ }^{144} \mathrm{Nd}_{\mathrm{i}}$ ratios have a wider spread from 0.512496-0.512673 (Fig. 8). Rocks from the ophiolites and associated granitoids have less radiogenic $\mathrm{Nd}$ isotope ratios than present-day mid ocean ridge basalt (MORB)-type mantle (Stracke et al. 2005). The gabbros have initial ${ }^{143} \mathrm{Nd} /{ }^{144} \mathrm{Nd}$ ratios similar to those of samples from the Jurassic Demir Kapija (Macedonia, FYROM) and Greek ophiolites (Zachariadis 2007; Koglin et al. 2009; Božović et al. 2013). The granitoids from the South Apuseni ophiolitic unit overlap with their isotopic composition with that of the andesitic and adakite-like volcanic rocks from FYROM (Božović et al. 2013). The Fanos granite (northern Greece) has slightly higher ${ }^{87} \mathrm{Sr} /{ }^{86} \mathrm{Sr}_{i}$ and lower ${ }^{143} \mathrm{Nd} /{ }^{144} \mathrm{Nd}_{\mathrm{i}}$ ratios than the South Apuseni granitoids (Anders et al. 2005; Šarić et al. 2009). Granitoids from Serbia and FYROM, in contrast, have distinctly higher ${ }^{87} \mathrm{Sr} /{ }^{86} \mathrm{Sr}$ ratios and lower ${ }^{143} \mathrm{Nd} /{ }^{144} \mathrm{Nd}$ ratios (Šarić et al. 2009). 
Table 1: Whole rock major (wt\%) and trace element (ppm) geochemistry of Apuseni ophiolitic rocks and associated granitoids analysed in this study.

\begin{tabular}{|c|c|c|c|c|c|c|c|c|c|c|}
\hline $\begin{array}{l}\text { Sample } \\
\text { Rock type }\end{array}$ & $\begin{array}{l}\text { DG062 } \\
\text { grd }\end{array}$ & $\begin{array}{l}\text { DG063 } \\
\text { diorite }\end{array}$ & $\begin{array}{l}\text { DG064 } \\
\text { gabbro }\end{array}$ & $\begin{array}{l}\text { DG065 } \\
\text { granite }\end{array}$ & $\begin{array}{l}\text { DG066 } \\
\text { basalt }\end{array}$ & $\begin{array}{l}\text { DG067 } \\
\text { rhyolite }\end{array}$ & $\begin{array}{l}\text { DG068 } \\
\text { gabbro }\end{array}$ & $\begin{array}{l}\text { DG072 } \\
\text { granite }\end{array}$ & $\begin{array}{l}\text { DG081 } \\
\text { andesite }\end{array}$ & $\begin{array}{l}\text { DG082 } \\
\text { gabbro } \\
\text { Căzăneşt }\end{array}$ \\
\hline locality & $\begin{array}{c}\text { Săvârşin } \\
46.0448\end{array}$ & $\begin{array}{c}\text { Săvârşin } \\
46.0448\end{array}$ & $\begin{array}{l}\text { Săvârşin } \\
46.0286\end{array}$ & $\begin{array}{c}\text { Săvârşin } \\
46.0268\end{array}$ & $\begin{array}{c}\text { Săvârşin } \\
46.0268\end{array}$ & $\begin{array}{l}\text { Săvârşin } \\
46.0627\end{array}$ & $\begin{array}{l}\text { Cerbia } \\
46.0367\end{array}$ & $\begin{array}{l}\text { Cerbia } \\
46.0554\end{array}$ & $\begin{array}{l}\text { Birtin } \\
46.1510\end{array}$ & i \\
\hline Latitude & $\begin{array}{c}6 \\
22.2760\end{array}$ & $\begin{array}{c}6 \\
22.2760\end{array}$ & $\begin{array}{c}4 \\
22.2672\end{array}$ & $\begin{array}{c}8 \\
22.2651\end{array}$ & $\begin{array}{c}8 \\
22.2651\end{array}$ & $\begin{array}{c}7 \\
22.2411\end{array}$ & $\begin{array}{c}0 \\
22.4464\end{array}$ & $\begin{array}{c}3 \\
22.4623\end{array}$ & $\begin{array}{c}0 \\
22.6299\end{array}$ & 46.15680 \\
\hline Longitude & 0 & 0 & 8 & 0 & 0 & 3 & 5 & 0 & 7 & 22.47152 \\
\hline $\begin{array}{l}\text { Igneous suite } \\
\text { U-Pb mean } \\
\text { age }\end{array}$ & $\begin{array}{l}\text { IAG } \\
158.6 \\
\mathrm{Ma}\end{array}$ & $\begin{array}{l}\text { oph } \\
155.9 \\
\mathrm{Ma}\end{array}$ & $\begin{array}{l}\text { oph } \\
157.7 \\
\mathrm{Ma}\end{array}$ & IAG & oph & $\begin{array}{l}\text { IAG } \\
155.0 \\
\mathrm{Ma}\end{array}$ & $\begin{array}{l}\text { oph } \\
158.9 \\
\mathrm{Ma}\end{array}$ & $\begin{array}{l}\text { IAG } \\
152.9 \\
\mathrm{Ma}\end{array}$ & IAG & $\begin{array}{l}\text { oph } \\
158.2 \mathrm{Ma}\end{array}$ \\
\hline $\mathrm{SiO}_{2}$ & 70.35 & 56.36 & 48.37 & 74.25 & 50.14 & 72.25 & 51.32 & 76.33 & 59.26 & 54.85 \\
\hline $\mathrm{TiO}_{2}$ & 0.41 & 0.66 & 0.57 & 0.20 & 1.16 & 0.26 & 0.35 & 0.14 & 0.60 & 2.95 \\
\hline $\mathrm{Al}_{2} \mathrm{O}_{3}$ & 14.82 & 16.89 & 18.93 & 13.49 & 15.19 & 14.19 & 16.30 & 12.71 & 17.11 & 15.61 \\
\hline $\mathrm{Fe}_{2} \mathrm{O}_{3 \mathrm{t}}$ & 3.17 & 6.30 & 6.64 & 1.48 & 10.87 & 1.95 & 6.58 & 0.78 & 3.42 & 2.94 \\
\hline $\mathrm{MnO}$ & 0.08 & 0.15 & 0.16 & 0.04 & 0.21 & 0.06 & 0.16 & 0.01 & 0.05 & 0.11 \\
\hline $\mathrm{MgO}$ & 0.92 & 5.36 & 7.44 & 0.26 & 7.60 & 0.42 & 8.60 & 0.03 & 1.54 & 4.81 \\
\hline $\mathrm{CaO}$ & 2.55 & 7.75 & 14.20 & 0.96 & 10.78 & 0.68 & 12.38 & 0.56 & 4.88 & 9.63 \\
\hline $\mathrm{Na}_{2} \mathrm{O}$ & 3.81 & 3.71 & 1.67 & 3.78 & 3.06 & 4.00 & 2.80 & 3.24 & 6.53 & 5.47 \\
\hline $\mathrm{K}_{2} \mathrm{O}$ & 2.70 & 0.68 & 0.20 & 4.85 & 0.35 & 5.11 & 0.16 & 4.93 & 1.32 & 0.56 \\
\hline $\mathrm{P}_{2} \mathrm{O}_{5}$ & 0.13 & 0.19 & 0.04 & 0.04 & 0.10 & 0.07 & 0.02 & 0.03 & 0.28 & 0.04 \\
\hline LOI & 1.28 & 1.81 & 1.99 & 0.49 & 0.88 & 0.92 & 1.42 & 0.68 & 4.93 & 3.02 \\
\hline Sum & 100.21 & 99.87 & 100.21 & 99.84 & 100.33 & 99.91 & 100.08 & 99.45 & 99.91 & 100.01 \\
\hline $\mathrm{Sc}$ & 10.6 & 22.2 & 36.3 & 2.6 & 42.2 & 2.2 & 38.7 & & 9.3 & 20.4 \\
\hline V & 55.6 & 134.4 & 189.7 & 13.2 & 275.9 & 24.7 & 144.5 & 9.1 & 86.8 & 221.9 \\
\hline $\mathrm{Cr}$ & & 192.1 & 240.2 & & 124.5 & & 142.0 & & 18.6 & 141.3 \\
\hline Co & 9.0 & 21.0 & 22.7 & 7.8 & 41.4 & 6.9 & 37.0 & 5.6 & 8.5 & 8.8 \\
\hline $\mathrm{Ni}$ & & 57.6 & 54.5 & & 22.5 & & 48.5 & & & 15.5 \\
\hline $\mathrm{Ga}$ & 12.8 & 11.6 & 11.6 & 12.6 & 13.3 & 12.5 & 9.7 & 11.6 & 11.0 & 14.4 \\
\hline $\mathrm{Rb}$ & 70.6 & 11.8 & 6.3 & 154.4 & 8.4 & 131.1 & 5.8 & 119.2 & 20.4 & 7.4 \\
\hline $\mathrm{Sr}$ & 320.5 & 363.1 & 370.3 & 176.9 & 145.7 & 167.7 & 214.3 & 143.8 & 573.3 & 258.2 \\
\hline Y & 23.1 & 16.2 & 11.5 & 17.7 & 26.3 & 15.7 & 10.5 & 13.7 & 22.6 & 78.0 \\
\hline $\mathrm{Zr}$ & 174.1 & 68.6 & 36.8 & 148.8 & 63.0 & 175.2 & 16.9 & 93.6 & 192.1 & 76.6 \\
\hline $\mathrm{Nb}$ & 4.5 & 2.1 & 1.0 & 17.3 & 1.1 & 16.3 & 0.2 & 12.8 & 7.1 & 10.0 \\
\hline Cs & 0.3 & 0.4 & 0.2 & 0.9 & 0.1 & 0.4 & 0.7 & 0.9 & 0.5 & 2.4 \\
\hline $\mathrm{Ba}$ & 552.1 & 75.0 & 23.5 & 581.8 & 41.1 & 958.8 & 22.1 & 1086.5 & 329.1 & 60.3 \\
\hline $\mathrm{La}$ & 25.3 & 12.0 & 4.5 & 49.7 & 3.6 & 60.6 & 0.8 & 35.5 & 43.7 & 24.3 \\
\hline $\mathrm{Ce}$ & 50.4 & 25.8 & 11.4 & 77.4 & 8.9 & 95.9 & 2.4 & 58.8 & 75.4 & 82.2 \\
\hline $\mathrm{Pr}$ & 5.8 & 3.1 & 1.7 & 7.1 & 1.5 & 8.5 & 0.4 & 6.4 & 8.9 & 12.1 \\
\hline $\mathrm{Nd}$ & 21.5 & 14.0 & 6.9 & 23.5 & 8.0 & 27.4 & 2.6 & 18.8 & 31.8 & 56.9 \\
\hline $\mathrm{Sm}$ & 4.8 & 3.3 & 2.2 & 4.2 & 3.0 & 3.7 & 1.0 & 3.2 & 5.8 & 14.1 \\
\hline $\mathrm{Eu}$ & 1.2 & 1.1 & 0.7 & 0.7 & 1.0 & 0.7 & 0.4 & 0.6 & 1.7 & 2.5 \\
\hline Gd & 3.8 & 3.3 & 2.3 & 3.0 & 3.7 & 3.2 & 1.4 & 2.8 & 4.9 & 15.1 \\
\hline $\mathrm{Tb}$ & 0.6 & 0.5 & 0.3 & 0.5 & 0.7 & 0.5 & 0.2 & 0.5 & 0.7 & 2.4 \\
\hline Dy & 3.7 & 2.9 & 1.9 & 2.8 & 4.2 & 2.9 & 1.9 & 2.6 & 4.2 & 15.1 \\
\hline Ho & 0.8 & 0.6 & 0.3 & 0.7 & 0.9 & 0.6 & 0.4 & 0.6 & 0.8 & 3.1 \\
\hline $\mathrm{Er}$ & 3.3 & 2.0 & 1.4 & 1.2 & 3.2 & 1.9 & 1.4 & 1.7 & 2.1 & 9.2 \\
\hline $\mathrm{Tm}$ & 0.6 & 0.3 & 0.2 & & 0.4 & 0.4 & 0.2 & 0.4 & 0.3 & 1.2 \\
\hline $\mathrm{Yb}$ & 3.7 & 1.4 & 1.0 & 3.2 & 2.8 & 2.2 & 1.3 & 2.2 & 2.2 & 8.0 \\
\hline $\mathrm{Lu}$ & 0.5 & 0.2 & 0.1 & 0.5 & 0.4 & 0.4 & 0.2 & 0.3 & 0.3 & 1.1 \\
\hline $\mathrm{Hf}$ & 5.0 & 1.7 & 1.1 & 4.6 & 2.2 & 4.7 & 0.6 & 3.8 & 4.6 & 2.3 \\
\hline $\mathrm{Ta}$ & 0.3 & 0.2 & 0.1 & 1.3 & 0.1 & 1.1 & 0.1 & 0.9 & 0.4 & 0.5 \\
\hline $\mathrm{Pb}$ & 1.5 & 1.5 & 1.6 & 5.6 & 2.0 & 6.9 & 1.6 & 7.8 & 11.4 & 0.4 \\
\hline Th & 8.1 & 3.6 & 1.0 & 42.1 & 0.3 & 35.8 & 0.1 & 27.1 & 13.0 & 4.5 \\
\hline $\mathrm{U}$ & 2.3 & 0.7 & 0.5 & 9.4 & 0.1 & 4.6 & 0.1 & 4.4 & 3.5 & 0.9 \\
\hline
\end{tabular}



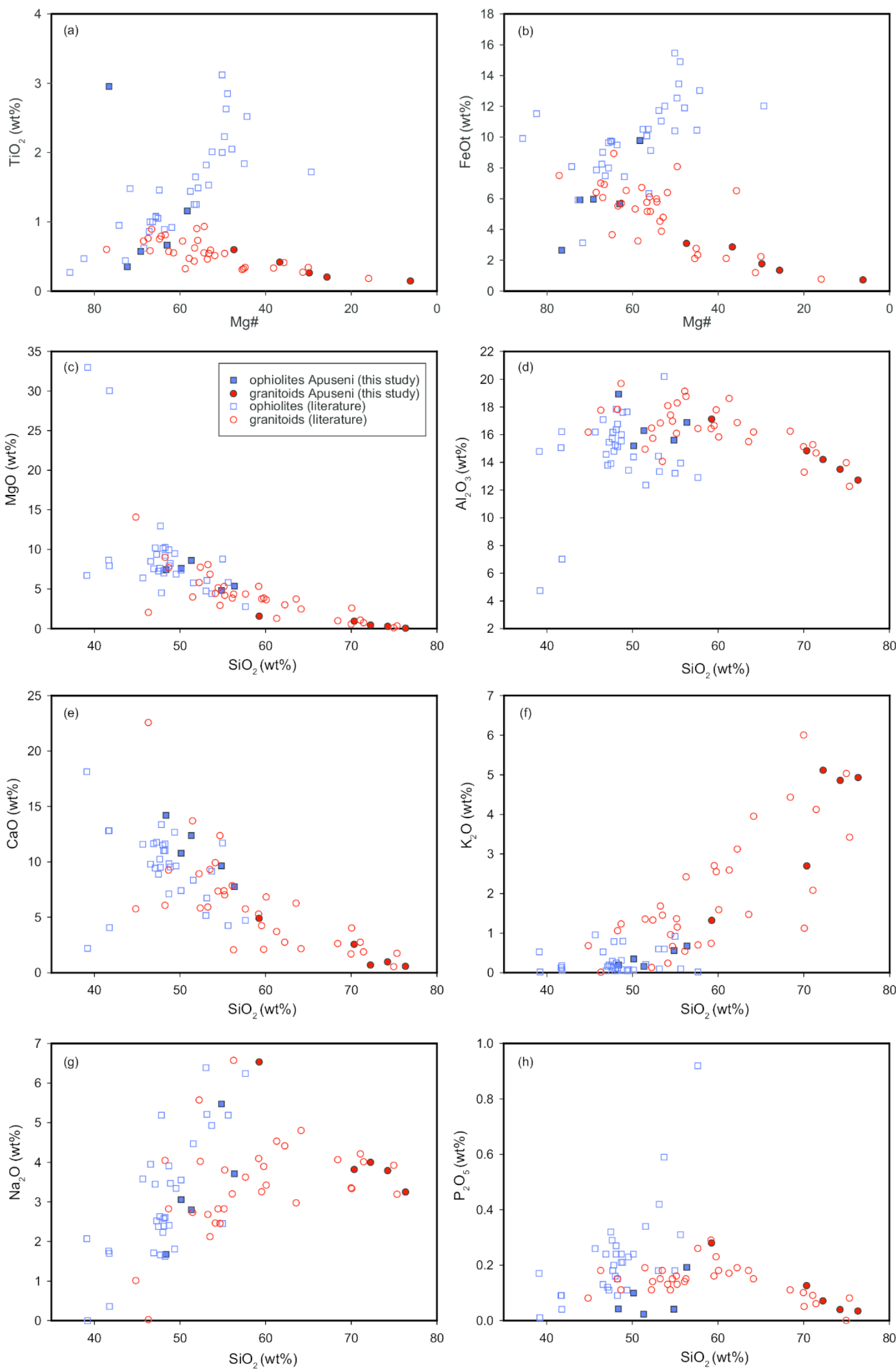

Figure 6: Variation diagrams for major element oxides. (a) and (b) $\mathrm{TiO}_{2}$ and $\mathrm{FeOt}$ versus $\mathrm{Mg \#}$. (c)-(h) $\mathrm{MgO}_{2} \mathrm{Al}_{2} \mathrm{O}_{3}, \mathrm{CaO}$, $\mathrm{K}_{2} \mathrm{O}, \mathrm{Na}_{2} \mathrm{O}$ and $\mathrm{P}_{2} \mathrm{O}_{5}$ versus $\mathrm{SiO}_{2}$. Apuseni ophiolite lithologies and associated granitoids from this study and from literature (Bortolotti et al. 2004) are plotted in the same diagrams. 

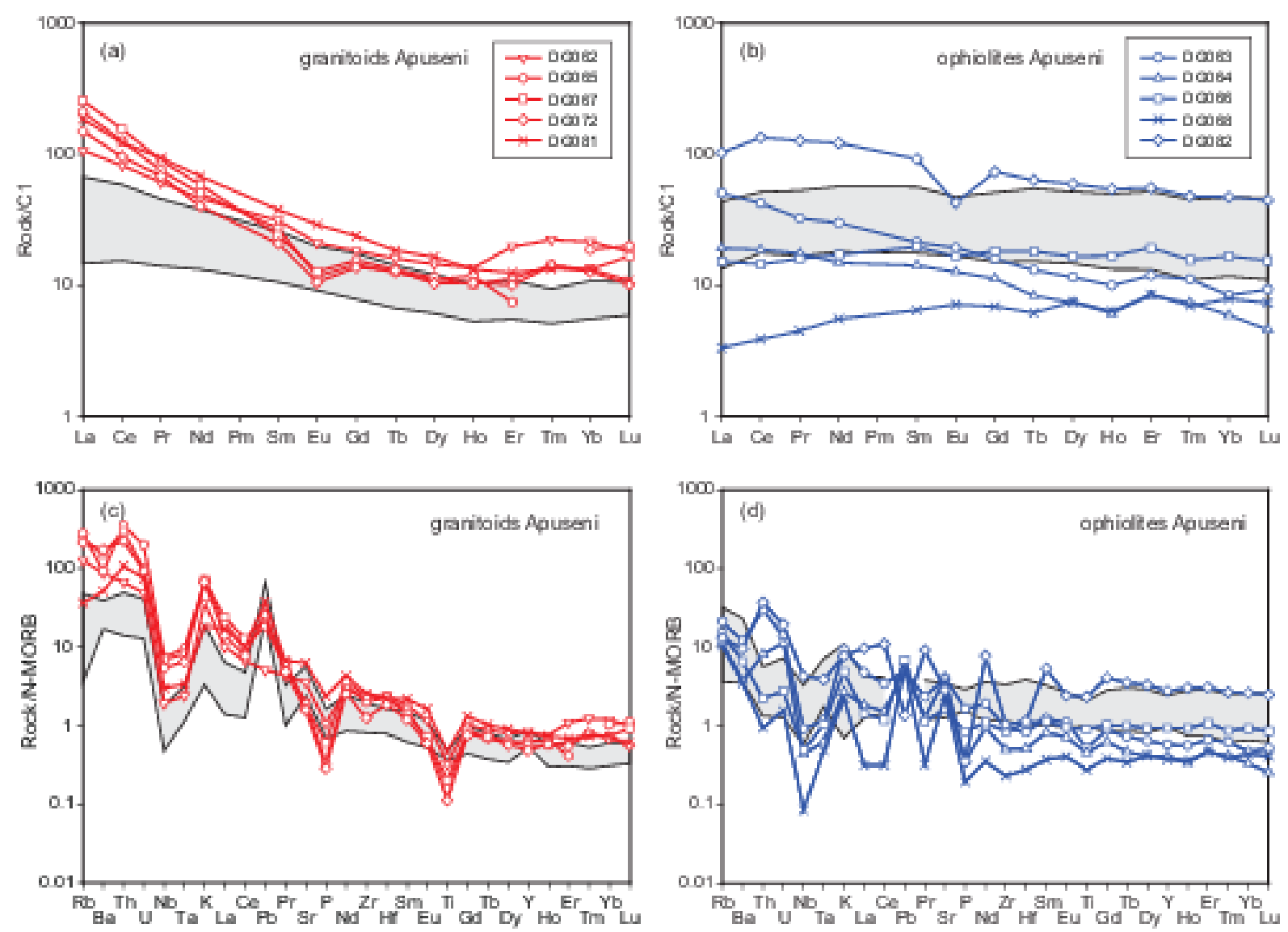

Figure 7: Trace element characteristics of the Apuseni ophiolite lithologies and associated granitoids. (a) and (b) Chondrite normalized rare earth element (REE) patterns. (c) and (d) N-MORB normalized trace element patterns. Gray bands indicate the range of data from Bortolotti et al. (2004). Normalization values are from Sun and McDonough (1989).

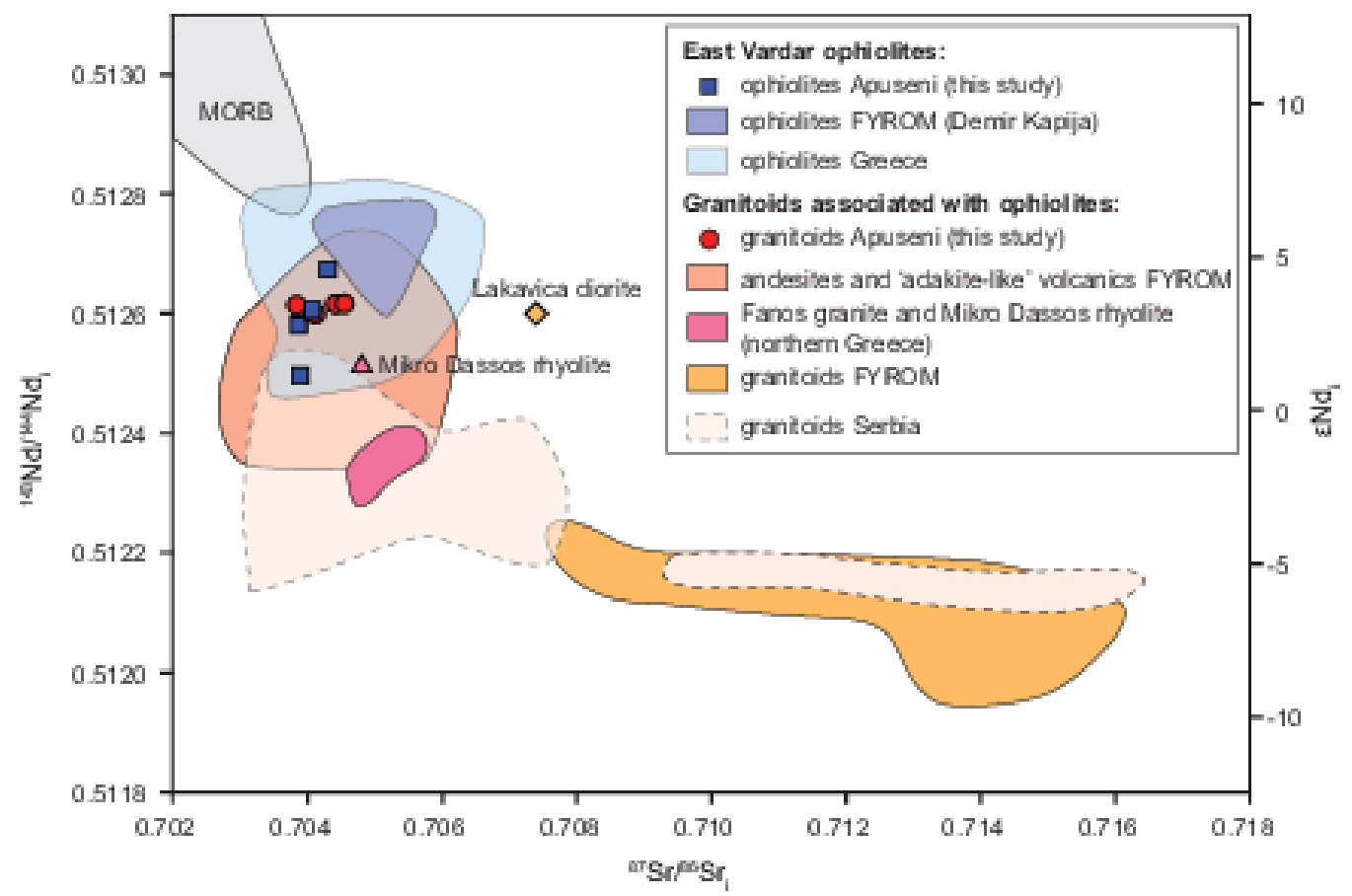

Figure 8: Initial $\mathrm{Sr}$ and $\mathrm{Nd}$ isotope ratios for the Apuseni ophiolite lithologies and associated granitoids from the South Apuseni ophiolitic unit. The isotope ratios were age corrected for $155 \mathrm{Ma}$ using the whole rock $\mathrm{Sr}, \mathrm{Rb}, \mathrm{Sm}$ and $\mathrm{Nd}$ concentrations. Field for present-day MORB is from Stracke et al. (2005); data for Greek ophiolitic rocks (Samothraki, Oraeokastro, Thessaloniki, Guevgueli, Sithonia and Kassandra) are from Zachariadis (2007) and Koglin et al. (2009); fields of Jurassic ophiolitic rocks and andesitic and 'adakite-like' volcanic rocks from FYROM (former 
Yugoslavian Republic of Macedonia) from Božović et al. (2013); high ${ }^{87} \mathrm{Sr} /{ }^{86} \mathrm{Sr}$ granitoids from FYROM, fields for the Fanos granite and Mikro Dassos rhyolite (northern Greece), and low and high ${ }^{87} \mathrm{Sr} /{ }^{86} \mathrm{Sr}$ granitoids from Serbia are from Šarić et al. (2009) and Anders et al. (2005).

Table 2: Sr and Nd isotopic data of Apuseni ophiolitic rocks and associated granitoids.

\begin{tabular}{|c|c|c|c|c|c|c|c|c|c|c|c|c|c|c|c|c|}
\hline Sample & $\begin{array}{l}\mathrm{Rb} \\
{[\mathrm{ppm}]}\end{array}$ & $\begin{array}{l}\mathrm{Sr} \\
{[\mathrm{ppm}]}\end{array}$ & ${ }^{87} \mathrm{Rb} /{ }^{86} \mathrm{Sr}$ & ${ }^{87} \mathrm{Sr} /{ }^{86} \mathrm{Sr}$ & & $2 \sigma$ & ${ }^{87} \mathrm{Sr}^{86} \mathrm{Sr}_{155 \mathrm{Ma}}$ & $\begin{array}{l}\mathrm{Nd} \\
{[\mathrm{ppm}]}\end{array}$ & $\begin{array}{l}\mathrm{Sm} \\
{[\mathrm{ppm}]}\end{array}$ & ${ }^{147} \mathrm{Sm} /{ }^{144} \mathrm{Nd}$ & ${ }^{143} \mathrm{Nd} /{ }^{144} \mathrm{Nd}$ & & $2 \sigma$ & ${ }^{143} \mathrm{Nd} /{ }^{144} \mathrm{Nd}_{155 \mathrm{Ma}}$ & $\varepsilon \mathrm{Nd}_{155 \mathrm{Ma}}$ & $\varepsilon \mathrm{Nd}_{0 \mathrm{Ma}}$ \\
\hline DG062 & 70.6 & 320.5 & 0.6200 & 0.705206 & \pm & 6 & 0.703836 & 21.5 & 4.8 & 0.1395 & 0.512755 & \pm & 4 & 0.512614 & 3.4 & 2.3 \\
\hline DG063 & 11.8 & 363.1 & 0.0900 & 0.704091 & \pm & 9 & 0.703889 & 14.0 & 3.3 & 0.1470 & 0.512645 & \pm & 16 & 0.512496 & 1.1 & 0.1 \\
\hline DG064 & 6.3 & 370.3 & 0.0500 & 0.703969 & \pm & 16 & 0.703863 & 6.9 & 2.2 & 0.1972 & 0.512781 & \pm & 7 & 0.512581 & 2.8 & 2.8 \\
\hline DG067 & 131.1 & 167.7 & 2.2100 & 0.708983 & \pm & 16 & 0.704121 & 27.4 & 3.7 & 0.0849 & 0.512685 & \pm & 4 & 0.512599 & 3.1 & 0.9 \\
\hline DG068 & 5.8 & 214.3 & 0.0800 & 0.704242 & \pm & 8 & 0.704074 & 2.6 & 1.0 & 0.2417 & 0.512851 & \pm & 18 & 0.512606 & 3.3 & 4.2 \\
\hline DG072 & 119.2 & 143.8 & 2.3400 & 0.709569 & \pm & 11 & 0.704414 & 18.8 & 3.2 & 0.1070 & 0.512724 & \pm & 6 & 0.512615 & 3.5 & 1.7 \\
\hline DG081 & 20.4 & 573.3 & 0.1000 & 0.704771 & \pm & 40 & 0.704550 & 31.8 & 5.8 & 0.1143 & 0.512732 & \pm & 4 & 0.512616 & 3.5 & 1.8 \\
\hline DG082 & 7.4 & 258.2 & 0.0800 & 0.704481 & \pm & 18 & 0.704303 & 56.9 & 14.1 & 0.1554 & 0.512831 & \pm & 6 & 0.512673 & 4.6 & 3.8 \\
\hline
\end{tabular}

\section{In situ U-Pb LA-ICP-MS zircon dating}

In order to improve the temporal evolution of the magmatic sequence of ophiolites and associated granitoids we dated 4 ophiolites and 5 associated granitoids (Tab. 3). A gabbro (DG064) and a diorite (DG063) that are part of the ophiolites, sampled close to the Săvârşin granitoid body (Fig. 3), yielded mean ${ }^{206} \mathrm{~Pb} /{ }^{238} \mathrm{U}$ ages of $157.7 \pm 2.57 \mathrm{Ma}$ (total age uncertainty comprising internal and external errors, $2 \sigma$ level) and $155.9 \pm 2.54 \mathrm{Ma}$, respectively. A gabbro (DG068) from the Cerbia area and another gabbro (DG082) from the ophiolites that occurs in association with the Căzăneşti granitoid (Fig. 3) have mean ${ }^{206} \mathrm{~Pb} /{ }^{238} \mathrm{U}$ ages of $158.9 \pm 2.75 \mathrm{Ma}$ and $158.2 \pm 2.54 \mathrm{Ma}$, respectively. Hence the mean ages obtained from the ophiolites vary between 158.9 and 155.9 Ma (Tab. 3, Fig. 9).

Table 3: ${ }^{206} \mathrm{~Pb} /{ }^{238} \mathrm{U}$ ages of Apuseni ophiolitic rocks and associated granitoids and volcanic equivalents. ${ }^{206} \mathrm{~Pb} /{ }^{238 \mathrm{U}}$ ages are weighted average ages calculated with Isoplot 3.75 (Ludwig 2012). The total uncertainty of the ages is at $2 \sigma$ level and comprises internal and propagated external errors. $\mathrm{N}$ number of zircons of the sample analysed; $\mathrm{N}^{*}$ number of zircons used for the age calculation.

\begin{tabular}{|c|c|c|c|c|c|c|c|c|c|}
\hline Sample & Rock Type & Igneous suite & Locality & $206 \mathrm{~Pb} /{ }^{238} \mathrm{U}$ Age & & $2 \sigma$ & $\mathrm{N}$ & $\mathrm{N}^{*}$ & MSWD \\
\hline DG063 & diorite & ophiolite & Săvârşin & 155.9 & \pm & 2.54 & 47 & 39 & 1.3 \\
\hline DG064 & gabbro & ophiolite & Săvârşin & 157.7 & \pm & 2.57 & 50 & 38 & 1.3 \\
\hline DG082 & gabbro & ophiolite & Căzănești & 158.2 & \pm & 2.54 & 46 & 41 & 1.1 \\
\hline DG068 & gabbro & ophiolite & Cerbia & 158.9 & \pm & 2.75 & 24 & 19 & 1.5 \\
\hline DG072 & granite & IAG & Cerbia & 152.9 & \pm & 2.49 & 34 & 25 & 1.1 \\
\hline DG081 & andesite & IAG & Birtin & 154.5 & \pm & 2.50 & 45 & 35 & 1.2 \\
\hline DG062 & granodiorite & IAG & Săvârşin & 158.6 & \pm & 2.52 & 41 & 25 & 2.3 \\
\hline DG067 & rhyolite & IAG & Săvârşin & 155.0 & \pm & 2.49 & 50 & 20 & 3.3 \\
\hline DG069 & granodiorite & IAG & Cerbia & 154.8 & \pm & 2.47 & 46 & 21 & 3.5 \\
\hline
\end{tabular}

The dated granitoids and volcanic equivalents have a tendency to be younger than the ophiolites, except for a granodiorite from the Săvârşin body (DG062) that yielded a mean ${ }^{206} \mathrm{~Pb} /{ }^{238} \mathrm{U}$ age of $158.6 \pm 2.52 \mathrm{Ma}$. A rhyolite sample (DG067) from the volcanic cover overlying the ophiolites located near the Săvârşin body yielded a mean ${ }^{206} \mathrm{~Pb} / 238 \mathrm{U}$ age of $155.0 \pm 2.49 \mathrm{Ma}$ (Fig. 3). Two granitoids from the Cerbia body (DG069, DG072) have mean ${ }^{206} \mathrm{~Pb} /{ }^{238 U}$ ages of $154.8 \pm 2.47$ and $152.9 \pm 2.49 \mathrm{Ma}$, respectively. An andesite sampled east of Căzăneşti (DG081, Fig. 3) is $154.5 \pm$ $2.50 \mathrm{Ma}$ old. In summary, the mean ages of the granitoids range from 158.6 to $152.9 \mathrm{Ma}$ (Tab. 3, Fig. 9). 


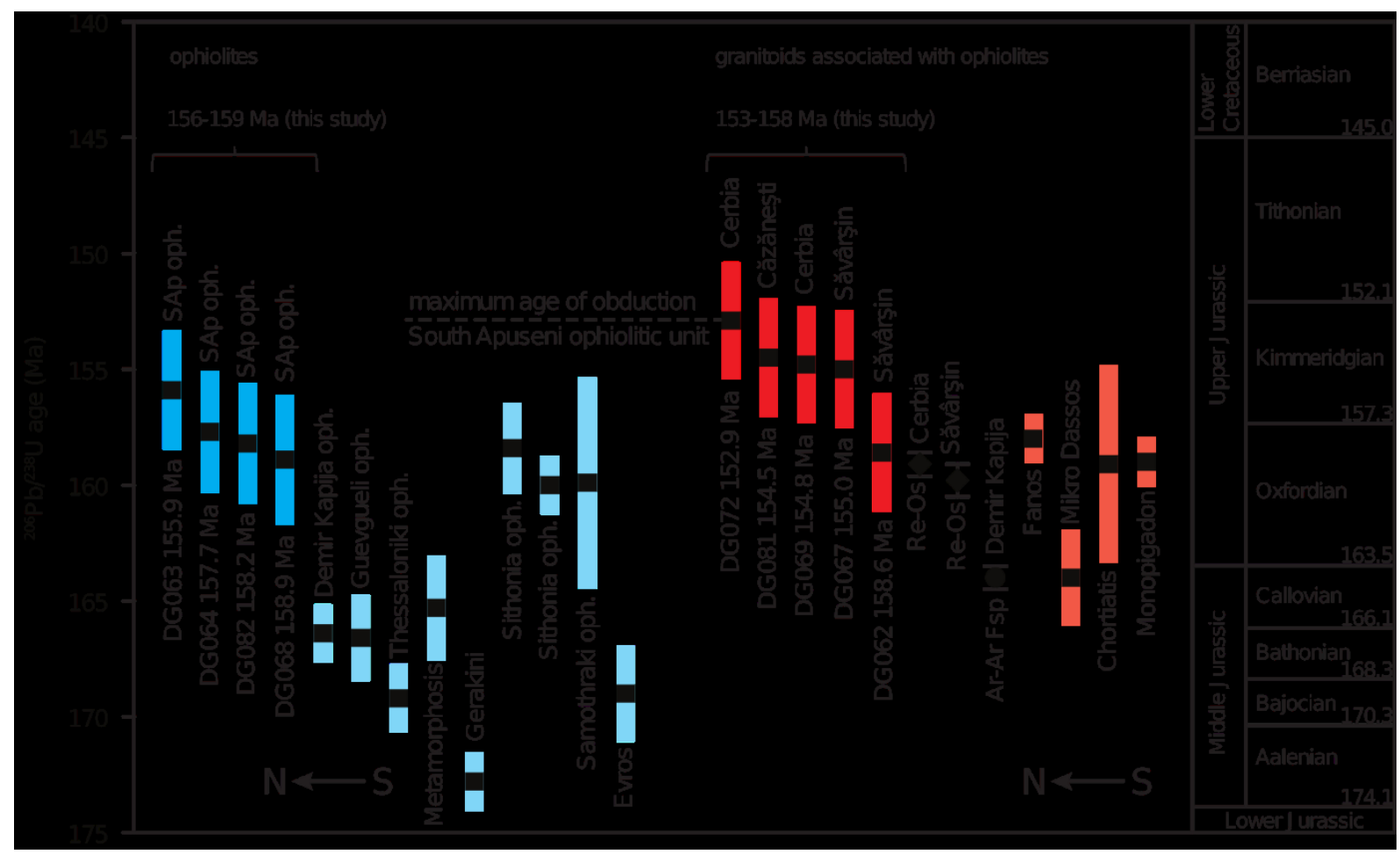

Figure 9: Mean ${ }^{206} \mathrm{~Pb} /{ }^{238} \mathrm{U}$ ages of ophiolites (blue error bars) and associated granitoids and their volcanic equivalents (red error bars) of the East Vardar ophiolites between Greece and Romania (chronostratigraphy after Cohen et al. 2013). The data is sorted geographically from north to south. ${ }^{206} \mathrm{~Pb} / 238 \mathrm{U}$ ages for the South Apuseni ophiolites and the Săvârşin, Cerbia and Căzăneşti granitoids and one rhyolite are from this study. U-Pb ages of the Sithonia, Metamorphosis, Guevgueli and Thessaloniki ophiolites (Greece) are from Zachariadis (2007) and Bonev et al. (2015). U-Pb ages of the Samothraki and Evros ophiolites (Greece) are from Koglin et al. (2007; 2009). U-Pb age of the Demir Kapija ophiolite (FYROM) and Ar-Ar Fsp age of a calc-alkaline rock associated with the Demir Kapija ophiolite are from (Božović et al. 2013). Re-Os ages for the Cerbia and Săvârşin granitoids are from Zimmerman et al. (2008). U$\mathrm{Pb}$ ages of the Fanos granite and the Mikro Dassos rhyolite (Greece) are from Anders et al. (2005), that of the Monopigadon granite (Greece) is from Meinhold et al. (2009). U-Pb age for the Chortiatis diorite (Greece) is from Zachariadis (2007), and that of the Gerakini diorite, interpreted to belong to ophiolites although enclosed within the Chortiatis island-arc suite, is from Bonev et al. (2015). A maximum age of obduction ( 153 Ma) of the South Apuseni ophiolitic unit can be inferred from the youngest calc-alkaline intrusive body (sample DG072). Note that the errors reported for literature data are standard-errors-of-the-mean, whereas the errors calculated for the Apuseni ophiolitic rocks and granitoids also include systematic external errors. This leads to seemingly larger errors of samples from this study.

\section{Discussion}

We now discuss the tectonic implications of the geochemical and geochronological data and compare them with data obtained from the remainder of the East Vardar ophiolites located further to the south. In accordance with previous studies addressing the East Vardar ophiolites, we use geochemical data to show that the ophiolites and granitoids and volcanic equivalents with an island arc affinity are genetically unrelated, and we will revisit the tectonic setting of the granitoids and their volcanic equivalents. The new age constraints provide valuable information about the age of ophiolite and granitoid formation in the Apuseni Mountains. They will also be used to refine existing geodynamic models (e.g. Bortolotti et al. 2002; Ionescu et al. 2009) regarding the emplacement of the East Vardar ophiolites in general on top of the continental Dacia Mega-Unit.

\section{Tectonic Significance of the Geochemical Data}

The geochemical characteristics show distinct differentiation trends for the BA- or MOR-type ophiolitic rocks on the one hand, and for the granitoids and volcanic equivalents with an island arc affinity on the other hand. The major element trends observed in the ophiolite lithologies and granitoids (Fig. 6), particularly the differences in the $\mathrm{TiO}_{2}$ and $\mathrm{FeOt}$ evolution with increasing differentiation (Bortolotti et al. 2004), indicate that they were not derived by 
fractionation from the same parental magma. Moreover, the elevated $\mathrm{K}_{2} \mathrm{O}$ contents and ubiquitous occurrence of potassium feldspar (Fig. 4b) in the granitoids differ from that of granites formed by magmatic differentiation from tholeiitic parental melts. The ophiolitic rocks follow a tholeiitic trend with high $\mathrm{FeOt} / \mathrm{MgO}$ ratios (Fig. 5), whereas most granitoids and their volcanic equivalents are depleted in FeOt, which is generally characteristic for calc-alkaline suites that experienced early crystallization and removal of Fe-Ti oxides (Miyashiro 1974).

The ophiolite lithologies characterized by relatively flat REE patterns (Fig. 7b) similar to modern mid ocean ridge basalts, but occasionally has slightly elevated LILE (Th and U) and a $\mathrm{Nb}$ depletion, which are both more typical for supra-subduction zone ophiolites (e.g. Dilek and Furnes 2011). The slightly steeper REE pattern of the youngest ophiolitic rock (DG063) might be explained by its formation towards the end of the tholeiitic MOR stage. In contrast to the ophiolitic rocks, the calc-alkaline granitoids are enriched in LILE (e.g. Ba, K, Pb) and LREE (La, $\mathrm{Ce}$ ) over HREE (Yb, Lu) (Figs. 7a and c). The granitoids also show depletions in HFSE (Nb, Ta) and pronounced negative Ti-anomalies. These particular trace element patterns are commonly taken as indicators of a subduction-enriched mantle source (e.g. Hawkesworth et al. 1997; Woodhead et al. 2001; Elliott 2003), although some of the enrichment observed in the granitoids might be attributed to magmatic differentiation. However, if the granitoids were formed by continuous fractional crystallization from tholeiitic melts, their REE patterns would be similar to those of the ophiolite lithologies, i.e. they would likely be less enriched in LREE (e.g. Floyd et al. 1998; Rollinson 2009). In summary, all this indicates that ophiolitic rocks and granitoids belong to different magmatic suites. The major and trace element characteristics of the ophiolite lithologies point to a mid ocean ridge (MOR) setting (Saccani et al. 2001; Bortolotti et al. 2002). However, this alone is not sufficient to exclude a marginal or back arc basin setting. Our chemical data show some features of supra-subduction zone ophiolites, which have also been observed by Ionescu et al. (2009). It is primarily the close temporal and spatial association of ophiolite lithologies and granitoids which leads to the proposal that the ophiolites probably formed in a marginal or back arc basin (Dilek and Furnes 2011). The calc-alkaline characteristics of the granitoids indicate a subduction-related origin (Bortolotti et al. 2002; Nicolae and Saccani 2003).

Nicolae and Saccani (2003) have shown that the observed mineral compositions and whole rock geochemical trends of the granitoids and their volcanic equivalents could be explained by closed-system fractional crystallization of a mantle-derived melt, and they therefore have argued for an island arc origin of the calc-alkaline igneous rocks. However, a crustal contribution is possible and would have implications for the tectonic setting. Because the major and trace element composition of continental crust is similar to that of subduction-related rocks (Rudnick and Gao 2014) crustal contamination can only be reliably detected by radiogenic isotopes, which have so far not been available for the South Apuseni granitoids. The granitoids and their volcanic equivalents in the Mureş valley are exclusively associated with ophiolites (Bortolotti et al. 2002). The granitoids intrude and crosscut all levels of the ophiolite sequence, and basaltic to rhyolitic calc-alkaline flows are deposited on top of the ophiolitic sequence (Bortolotti et al. 2002). Although no contacts of the calc-alkaline granitoids with the underlying continental Biharia nappe system are exposed in the Apuseni Mountains, the granitoids might still have cut through the underlying continental unit in unexposed parts of the contact.

In the southern parts of the East Vardar ophiolites in Serbia, FYROM and Greece, the granitoids are not only associated with ophiolitic bodies but partly also with continental units, which is clearly reflected in their high initial ${ }^{87} \mathrm{Sr} /{ }^{86} \mathrm{Sr}$ ratios and low initial ${ }^{143} \mathrm{Nd} /{ }^{144} \mathrm{Nd}$ ratios (Fig. 8) (Anders et al. 2005; Šarić et al. 2009). These granitoids were not formed in an island arc, but due to subduction under a continental ribbon or in a collisional to post-collisional setting (Šarić et al. 2009). The initial Sr and Nd isotope ratios of the granitoids from the Mureş valley, however, do not indicate any substantial crustal contribution (Fig. 8). The granitoids' initial ${ }^{87} \mathrm{Sr} /{ }^{86} \mathrm{Sr}$ ratios ( 0.703836 to 0.704550 ) and initial ${ }^{143} \mathrm{Nd} /{ }^{144} \mathrm{Nd}$ ratios (0.512599 to 0.512616 ) overlap with the gabbros from the ophiolitic series in the Apuseni Mountains, Greece and FYROM (Fig. 8). 
Compared to MORB-type mantle, the Nd isotope ratios of rocks from the East Vardar ophiolites are less radiogenic, which probably indicates that the mantle source of the East Vardar ophiolite lithologies was slightly subduction-enriched. The similar isotope ratios of the granitoids and the ophiolitic rocks might thus be a feature of the subduction-enriched mantle source or, alternatively, might point to the involvement of oceanic crust in the formation of the granitoids. Additionally, the $\mathrm{Sr}$ and $\mathrm{Nd}$ isotope systematics of the granitoids from the Mureș valley resemble Jurassic subduction-related rocks associated with the Demir Kapija ophiolites in Macedonia (FYROM; Fig. 8; Božović et al. 2013). Hence, the Sr and Nd isotope systematics of the South Apuseni granitoids are consistent with their formation in a subduction-related island arc on oceanic crust (Bortolotti et al. 2002; Nicolae and Saccani 2003).

\section{Tectonic Significance of the U-Pb Zircon Ages}

The new geochronological data from the Apuseni Mountains indicate that the ophiolites and the island arc granitoids and their subvolcanic and volcanic equivalents formed within a surprisingly short time interval (Fig. 9, Tab. 3). Mean ${ }^{206} \mathrm{~Pb} /{ }^{238} \mathrm{U}$ ages obtained for tholeiitic gabbros from South Apuseni ophiolites range from 159 to 156 Ma (Late Oxfordian-Early Kimmeridgian). The island arc granitoids (the Săvârşin and Cerbia bodies) yielded mean ${ }^{206} \mathrm{~Pb} /{ }^{238} \mathrm{U}$ ages between 159 and $153 \mathrm{Ma}$ (Late Oxfordian-Late Kimmeridgian), and a rhyolite and an andesite with island-arc affinities yielded ages of $156 \mathrm{Ma}$ and $154 \mathrm{Ma}$ (Early Kimmeridgian), respectively. The new U-Pb zircon ages for the Cerbia and Săvârşin granitoids are partly younger than the Re-Os ages $(159.1 \pm 0.5$ and $159.8 \pm 0.7 \mathrm{Ma})$ of molybdenites associated with the granitoids reported by Zimmerman et al. (2008), which might be explained by prolonged crystallization of the calc-alkaline intrusions. The new U-Pb ages of the ophiolites and the granitoids overlap within error, which implies that back-arc spreading and subductionrelated magmatic activity must have occurred within a narrow time range. Nevertheless, the granitoids tend to have slightly younger mean ages than rocks from the ophiolites (Fig. 9, Tab. $3)$.

Radiometric age constraints are also available for ophiolites and associated granitoids in the Greek and Macedonian (FYROM) parts of the East Vardar ophiolites (Fig. 9, Tab. 4). The mean U$\mathrm{Pb}$ ages of rocks from the ophiolites range from $172.8 \pm 1.2$ to $158.4 \pm 1.9 \mathrm{Ma}$ (Koglin et al. 2007; Zachariadis 2007; Koglin et al. 2009; Božović et al. 2013; Bonev et al. 2015). The granitoids and their volcanic equivalents yielded mean $\mathrm{U}-\mathrm{Pb}$ ages between $164.0 \pm 2$ and $158 \pm 1 \mathrm{Ma}$ (Anders et al. 2005; Zachariadis 2007; Meinhold et al. 2009), and an Ar-Ar feldspar age of $164 \pm 0.5 \mathrm{Ma}$ (Božović et al. 2013). On the whole, the ophiolites and granitoids from the southern parts of the East Vardar ophiolites tend to be older than their counterparts in the Apuseni Mountains although the age ranges overlap. The wide range of radiometric ages of the ophiolite lithologies (Aalenian to Late Oxfordian) indicates that they did not form simultaneously within the back-arc basins of the East Vardar branch of Neotethys, but that back-arc spreading shifted from the southern to the northern parts. Interestingly, the total range of ages obtained for rocks from the East Vardar ophiolites is almost identical with the age range obtained for the metamorphic soles in the West Vardar ophiolites (174-157 Ma; Schmid et al. 2008 and references therein) that formed during intra-oceanic subduction within Neotethys. This, and the lack of ophiolitic rocks older than Aalenian ( 174-170 Ma) in age, supports the concept of back-arc spreading behind an intra-oceanic subduction zone within the northern branch of Neotethys. This will be discussed later. Also when considering the entire area of the East Vardar ophiolites the granitoids have a tendency to be younger than the ophiolitic rocks (Tab. 4). In parts of the Greek and Macedonian (FYROM) East Vardar ophiolite unit the intrusive contact of granitoids into ophiolitic rocks is actually visible (e.g. Anders et al. 2005). At all locations the time-lag between ophiolites and granitoids ranges from $\sim 2.5$ (Demir Kapija and Guevgueli) to $10 \mathrm{Ma}$ (Thessaloniki). The difference may be explained by the slightly different tectonic settings and/or the different stages at which the granitoids formed. The very small age difference observed in the case of rocks from the Demir Kapija and Guevgueli ophiolites argues for granitoid formation in an island arc setting. 
Table 4: Previously published U-Pb, Ar-Ar, and Re-Os ages of East Vardar ophiolites and associated granitoids. Ages were published in Anders et al. (2005), Zachariadis (2007), Koglin et al. (2007; 2009), Zimmerman et al. (2008), Meinhold et al. (2009), Božović et al. (2013) and Bonev et al. (2015).

\begin{tabular}{llrllll}
\hline Locality & Rock type & Age & $2 \sigma$ & & Age type & Author \\
\hline East Vardar ophiolites: & & & & & \\
Demir Kapija & gabbro & 166.4 & \pm 1.2 & Ma & U-Pb & Božović et al., 2013 \\
Guevgueli & plagiogranite & 166.6 & \pm 1.8 & Ma & U-Pb & Zachariadis, 2007 \\
Thessaloniki & diorite & 169.2 & \pm 1.4 & Ma & U-Pb & Zachariadis, 2007 \\
Metamorphosis & hbl-gabbro & 165.3 & \pm 2.2 & Ma & U-Pb & Zachariadis, 2007 \\
Gerakini & diorite & 172.8 & \pm 1.2 & Ma & U-Pb & Bonev et al., 2015 \\
Sithonia & gabbro & 158.4 & \pm 1.9 & Ma & U-Pb & Bonev et al., 2015 \\
Sithonia & diorite & 160.0 & \pm 1.2 & Ma & U-Pb & Zachariadis, 2007 \\
Samothraki & gabbro & 159.9 & \pm 4.5 & Ma & U-Pb & Koglin et al., 2009 \\
Evros & gabbro & 169 & \pm 2 & Ma & U-Pb & Koglin et al., 2007 \\
Granitoids including & volcanic equivalents associated with East & Vardar ophiolites: \\
Cerbia & granite & 159.1 & \pm 0.5 & Ma & Re-Os & Zimmerman et al., 2008 \\
Săvârşin & granite & 159.8 & \pm 0.7 & Ma & Re-Os & Zimmerman et al., 2008 \\
Demir Kapija & arc lavas & 164.0 & \pm 0.5 & Ma & Ar-Ar & Božović et al., 2013 \\
Fanos & granite & 158 & \pm 1 & Ma & U-Pb & Anders et al., 2005 \\
Mikro Dassos & rhyolite & 164 & \pm 2 & Ma & U-Pb & Anders et al., 2005 \\
Chortiatis & diorite & 159.1 & \pm 4.2 & Ma & U-Pb & Zachariadis, 2007 \\
Monopigadon & granitoid & 159.0 & \pm 1.0 & Ma & U-Pb & Meinhold et al., 2009 \\
\hline
\end{tabular}

The timing of obduction of the East Vardar ophiolites that presently overlie the continental Dacia Mega-Unit is not constrained by direct radiometric dating, and a metamorphic sole has so far not been detected in the East Vardar ophiolites. In the case of the Apuseni Mountains, the timing of obduction can only be estimated by using two independent approaches. Firstly, obduction must have occurred before the deposition of Late Jurassic to Early Cretaceous shallow water carbonates (Bucur and Săsăran 2005), which unconformably overlie the South Apuseni ophiolitic unit as well as the continental basement units in their footwall (Kounov and Schmid 2013). The age of deposition of such shallow water limestones in the Mureș valley and in the Trascău Mountains is Early Kimmeridgian-Tithonian (157-145 Ma) (Şerban et al. 2004; Bucur and Săsăran 2005). Secondly, the new U-Pb ages of the island arc series associated with the ophiolites put an additional constraint on the timing of obduction. As discussed earlier, the low initial ${ }^{87} \mathrm{Sr} /{ }^{86} \mathrm{Sr}$ and high initial ${ }^{143} \mathrm{Nd} /{ }^{144} \mathrm{Nd}$ ratios of the granitoids in the Apuseni Mountains indicate that no crustal contamination occurred. This, in turn, excludes the possibility that the granitoids formed in a collisional to post-collisional setting that involved the continental margin; the lack of crustal contamination rather implies that the granitoids intruded the ophiolite sequence before joint emplacement onto the continental Dacia Mega-Unit. Final obduction onto the continental edge can therefore only have started after intrusion of the youngest island arc granitoid. The age of the youngest dated granitoid, i.e. $152.9 \pm 2.49$ Ma (Late Kimmeridgian; DG072; Tab.3, Fig. 9), yields a second estimate for the maximum age of obduction of the South Apuseni ophiolitic unit. It has to be noted, however, that the second maximum age estimate of obduction ( $153 \mathrm{Ma}$, Late Kimmeridgian) is some 4 millions of years younger than the biostratigraphic constraints (157 Ma, Oxfordian-Kimmeridgian boundary). This discrepancy may well reflect errors in the radiometric age $( \pm 2.49$ Ma for the youngest granitoid $)$ and/or the conversion of biostratigraphic ages to absolute ages. 


\section{Geodynamic Model}

Here, we use our findings to improve and/or revise earlier tectonic models for the Jurassic evolution of the South Apuseni ophiolitic unit (Bortolotti et al. 2002; Csontos and Vörös 2004; Schmid et al. 2008; Ionescu et al. 2009; Kounov and Schmid 2013) and compare the tectonic history of the ophiolites in the Apuseni Mountains with other ophiolites from the East Vardar realm. Moreover, we revise paleogeographic reconstructions of the Alpine-Carpathian-DinarideRhodope-Balkan area for the Jurassic (e.g. Schmid et al. 2008) (Figs. 10a and b). Based on the new geochemical data and U-Pb ages, we distinguish three distinct events in the Jurassic, (1) back-arc ophiolite formation in the Oxfordian to Early Kimmeridgian ( $160 \mathrm{Ma}),(2)$ roll-back of the intra-oceanic subduction and generation of an island arc mainly in the Early Kimmeridgian ( $\sim 157 \mathrm{Ma})$, and (3) obduction starting in the latest Kimmeridgian to Tithonian ( 152 Ma) (Figs. $10 \mathrm{c}, \mathrm{d}$ and $\mathrm{e})$.
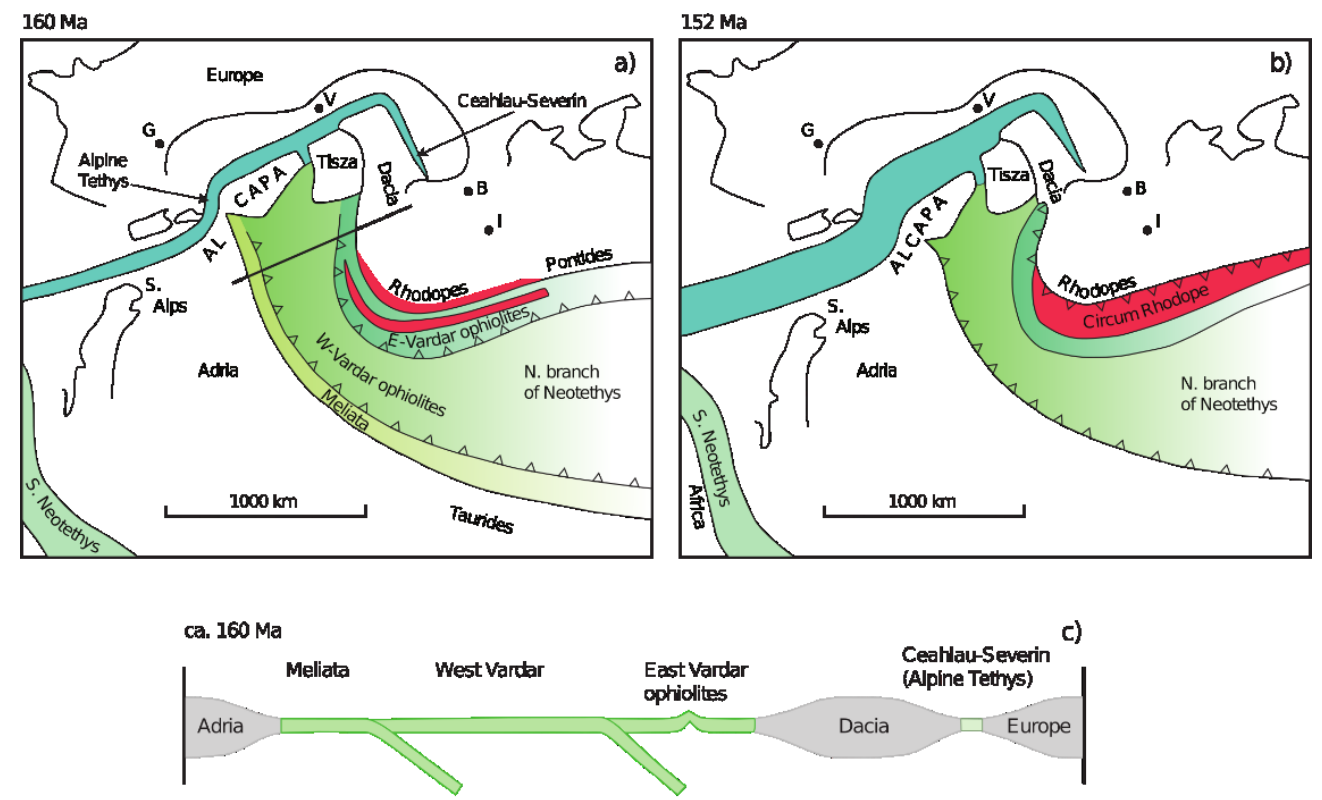

c)
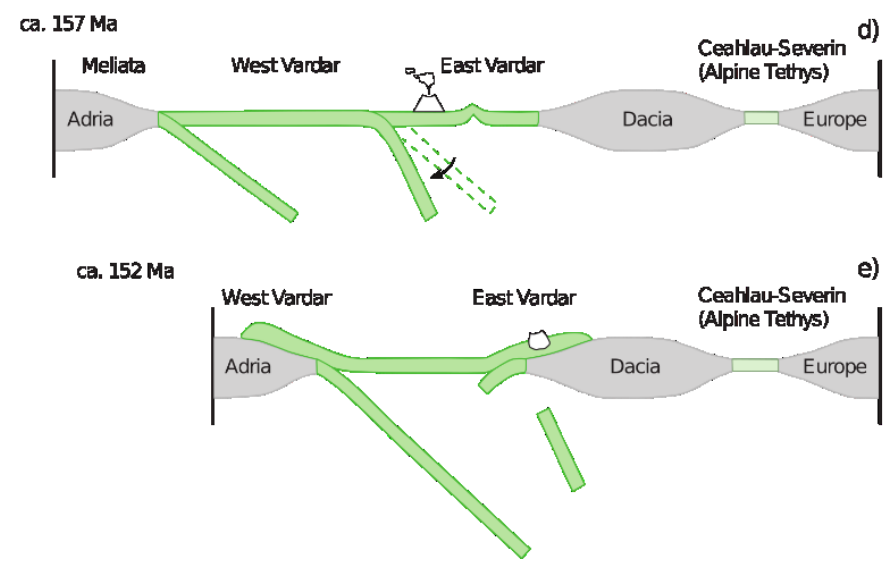

Figure 10: Paleogeographic sketch maps and profiles for $160 \mathrm{Ma}$ (Oxfordian) and $152 \mathrm{Ma}$ (Kimmeridgian-Tithonian boundary), respectively. The figures are modified after Schmid et al. (2008), Kounov and Schmid (2013) and Božović et al. (2013); they also take into account that the ALCAPA, Tisza, and Dacia Mega-Units rifted off Europe side by side when the Alpine Tethys opened (e.g. Klötzli et al. 2004), and partly follow unpublished GPlates reconstructions by Douwe van Hinsbergen. While certain details in Figures 10a,b remain speculative, the evolutionary scheme presented in Figures 10c,d is strongly supported by the new data presented. The abbreviations for cities in (a) and (b) are as follows: G Geneva; V Vienna; B Bucharest; I Istanbul. (a) Figure illustrating spreading in an intra-oceanic back arc basin in the South Apuseni area; in Macedonia (FYROM) and Greece back arc spreading was ensialic and split off a continental fragment of the Circum-Rhodope belt; the Paikon arc formed on this continental fragment; (b) figure showing the emplacement of East Vardar ophiolites and Circum-Rhodope belt onto Dacia. Note that the so-called Circum-Rhodope realm includes E-Vardar ophiolites, island arc complexes and Dacia-derived continental crust (e.g. Bonev et al. 2015); (c), (d), (e) Schematic cross sections (not to scale) showing evolution steps of the South Apuseni ophiolites during the Late Jurassic. (c) Formation of the South Apuseni ophiolites in a back-arc basin ( 160 Ma, 
Oxfordian). (d) Slab roll-back in the East Vardar realm and onset of island arc magmatism within the Apuseni ophiolites ( 157 Ma, Early Kimmeridgian). (e) Collision of the Apuseni island arc with the Dacia Mega-Unit and obduction of the ophiolites and island arc granitoids onto the continental margin. A similar evolution occurred in the southern parts of the East Vardar ophiolites that are now part of the Circum-Rhodope belt (Zachariadis 2007; Božović et al. 2013), where a continental arc (Paikon arc) formed on a narrow continental ribbon that split off the Dacia MegaUnit (see a).

In the Oxfordian to Early Kimmeridgian ( 160 Ma), the Neotethys Ocean started to close along two distinct NE-dipping subduction zones, concomitantly with opening of the Alpine Tethys further north (Figs. 10a and c). The southwestern subduction zone later led to the obduction of the West Vardar ophiolites in the Dinarides (e.g. Schmid et al. 2008), the northeastern one led to back-arc spreading in the East Vardar marginal basin where new oceanic crust formed within a peripheral basin of Neotethys, as is evidenced by the published and new U-Pb ages of ophiolites. The geochemical data of the ophiolitic rocks show a subtle subduction influence and indicate that the ophiolites probably did not form in a typical mid ocean ridge setting (Saccani et al. 2001; Bortolotti et al. 2002), but in a marginal or remnant back arc basin of the Neotethys Ocean. Refining previous models (e.g. Bortolotti et al. 2004; Ionescu et al. 2009; Kounov and Schmid 2013), we propose that the back-arc basin, within which the Apuseni ophiolites formed, continued all the way through Serbia and Macedonia (FYROM) to Greece (Fig. 10a). In Macedonia (FYROM) and Greece, such back arc spreading within the East Vardar ophiolites split off a continental ribbon from the originally Dacia-derived parts of the Circum-Rhodope tectonic unit (Bortolotti et al. 2013) (Fig. 10a). The back-arc spreading apparently started earlier in the southern parts of the East Vardar marginal basin, at $\sim 170 \mathrm{Ma}$, and was restricted to the Middle Jurassic (Koglin et al. 2007; Zachariadis 2007; Božović et al. 2013; Bonev et al. 2015), whereas the oceanic lithosphere preserved in the South Apuseni ophiolitic unit is younger and Late Jurassic (Fig. 9). The reason for this north-ward (in present-day coordinates) propagation of ocean floor formation remains unclear.

In the Early Kimmeridgian ( $\sim 157 \mathrm{Ma}$ ), following back-arc spreading, and formation of the East Vardar ophiolites, the South Apuseni granitoids formed probably due to roll back of a NEdipping intra oceanic subduction zone (Fig. 10d). In the Apuseni Mountains, the granitoids and associated subvolcanic and volcanic rocks exclusively intruded ophiolites and probably represent an early island arc series, which is consistent with the $\mathrm{Sr}$ and $\mathrm{Nd}$ isotope ratios and the reported occurrence of boninites in the subsurface of the Transylvanian basin (Ionescu et al. 2009). In our model, the dip direction of this intra-oceanic subduction zone is NE to $E$ (in Jurassic coordinates) and remained unchanged after back-arc spreading (Fig. 10d). In the Apuseni Mountains, this intra-oceanic subduction induced island-arc magmatic activity within an oceanic realm, whereas in Macedonia (FYROM) and Greece subduction beneath the split-off continental ribbon led to formation of a magmatic arc on continental crust (e.g. Paikon arc, Fanos granite) (Fig. 10a). Permian and Carboniferous ages have been reported for the continental basement (Anders et al. 2005) occurring with the Fanos granite, which is associated with the Guevgueli ophiolites, and these ages coincide with ages found in the Circum-Rhodope unit (Turpaud 2006).

Since the ophiolites and associated granitoids of the East Vardar realm were emplaced onto the adjacent Dacia Mega-Unit (Kounov and Schmid 2013) the NE-dipping intra-oceanic subduction must eventually have ceased to be active in the East Vardar realm (Figs. 10b and e). Obduction of the Apuseni ophiolitic unit and other parts of the East Vardar ophiolites including the CircumRhodope continental fragments was probably associated with a flip in subduction polarity (Fig. 10e). This change to SW-dipping subduction polarity likely happened suddenly and led to collision of the island arc (in the case of the Apuseni Mountains) and the Circum-Rhodope continental ribbon (in FYROM and Greece) with the Dacia Mega-Unit. The collision eventually resulted in marginal obduction of the ophiolites and island arc series onto the Dacia Mega-Unit. In contrast to this East Vardar scenario, the obduction of the West Vardar ophiolites occurred above a long-lived NE-dipping subduction zone that is associated with the formation of metamorphic soles (subduction zone in the SW; Fig. 10a) (Gaggero et al. 2009; Bortolotti et al. 
2013; Borojević Šoštarić et al. 2014). The latter have not been found in the East Vardar ophiolites (Kounov and Schmid 2013). This probably indicates that the emplacement of the East Vardar ophiolites ultimately represents an arc-continent collision rather than a classic obduction as in the case of the West Vardar ophiolites (e.g. Bortolotti et al. 2013; Borojević Šoštarić et al. 2014) and the Semail ophiolite (e.g. Searle and Cox 1999). Note that the present-day location of the ophiolitic units of the Apuseni Mountains and the Transylvanian basin as depicted in Figure 1 differs from their more southerly position shown in Figures 10a, b. This is due to the considerable $\mathrm{N}$-directed (in Lower Cretaceous coordinates) displacement of the highest tectonic units within the Dacia Mega-Unit, i.e. the Biharia nappe system and overlying ophiolites. The displacement was associated with Lower Cretaceous nappe piling (top-E in present-day coordinates, i.e. after Cenozoic clockwise rotation of the Tisza-Dacia Mega-Units; e.g. Márton et al. 2007) from 130 Ma onwards (e.g. Săndulescu 1994; Kounov and Schmid 2013; their "Austrian" orogeny). Note also that the scenario depicted in Figures 10a,b contradicts the hypothesis that the Apuseni ophiolites formed a suture zone between the Tisza and Dacia MegaUnits (e.g. Schmid et al. 2008; Kounov and Schmid 2013), favoring the model of a single TiszaDacia continent (e.g. Csontos and Vörös 2004; Reiser 2015).

The timing of the obduction in the Apuseni Mountains is constrained by the new $\mathrm{U}-\mathrm{Pb}$ ages of the granitoids, which formed during the intra-oceanic island arc stage. Accordingly, obduction can only have started after intrusion of the youngest granitoid at 153 Ma (latest Kimmeridgian). This age is 4 Ma younger than that inferred from shallow water carbonates (Oxfordian/ Early Kimmeridgian, $\sim 157 \mathrm{Ma}$ ) unconformably overlying obducted ophiolites and continental basement (Şerban et al. 2004; Bucur and Săsăran 2005). In the area of the Demir Kapija ophiolites (FYROM), shallow water carbonates overlying post-obduction transgression conglomerates covering the ophiolites have a Tithonian to earliest Berriasian age ( $152-145$ Ma) (Kukoč et al. 2015). This clearly post-dates the intrusion of the Fanos granite (158 Ma) (Anders et al. 2005) associated with these ophiolites and constrains the timing of obduction in the Demir Kapija area rather precisely and within a time range (158-152 Ma) that is very similar to that obtained for the Apuseni Mountains. The Late Jurassic emplacement of the East Vardar ophiolites in the Apuseni Mountains was followed by Early Cretaceous thrusting of the East Vardar ophiolites across the present-day Transylvanian basin all the way to the Eastern Carpathians (Gröger et al. 2013) and also led to the collision of the Dacia and Tisza Mega-Units in the area of the Apuseni Mountains during the Early Cretaceous orogeny (e.g. Kounov and Schmid 2013).

\section{Conclusions}

This contribution documents the Late Jurassic magmatic and tectonic evolution of ophiolites and associated granitoids including their subvolcanic and volcanic equivalents exposed in the South Apuseni ophiolitic unit as of a short-lived sequence of back-arc spreading, island arc formation and arc-continent collision. It also proposes that the South Apuseni ophiolites do indeed represent the northern continuation of the East Vardar ophiolites (e.g. Schmid et al. 2008), including the ophiolites within the Circum-Rhodope belt. The main outcomes of this study, based on the new geochronological and geochemical data, are:

The Apuseni ophiolitic rocks are not pristine MOR-type ophiolites as previously proposed, but show a subtle subduction influence, which suggests that they rather formed in a back-arc marginal basin (BA-type ophiolites).

The low ${ }^{87} \mathrm{Sr} /{ }^{86} \mathrm{Sr}$ and high ${ }^{143} \mathrm{Nd} /{ }^{144} \mathrm{Nd}$ ratios of the calc-alkaline granitoids and their subvolcanic and volcanic equivalents associated with the Apuseni ophiolites indicate that crustal contamination did not occur. This is consistent with their previously proposed origin in an island arc setting.

The U-Pb ages indicate that the two distinct magmatic suites formed within a narrow time range in the Late Jurassic. The BA-type ophiolites as well as the granitoids and their subvolcanic and 
volcanic equivalents with island-arc affinity, are slightly younger in the Apuseni Mountains compared to the southern parts of the East Vardar ophiolites extending into the CircumRhodope belt.

Due to the lack of crustal contamination, the granitoids in the Apuseni Mountains must have intruded the ophiolites during the island arc stage and before their joint emplacement on top of the continental Dacia Mega-Unit after 153 Ma.

It is suggested that the Apuseni ophiolites, and later also the granitoids, formed above a steady NE-dipping subduction zone and in close vicinity to the continental Dacia Mega-Unit.

The steady NE-directed subduction was followed by a flip of subduction polarity, which triggered the emplacement of the ophiolites and island arc assemblage onto the continental Dacia Mega-Unit. This emplacement differs from the classic obduction scenario, and is better referred to as an island arc-continent collision.

\section{Acknowledgements}

This study was supported by the Swiss National Science Foundation grants 200020-146681 and 20021-146651 and SNF scopes projects JRP 7BUPJ062396 and IZ73ZO_128089. Douwe van Hinsbergen and Kamil Ustaszewski are thanked for sharing their ideas concerning plate tectonic reconstructions, influencing parts of our Figure 10. We thank Ramon Aubert, Markus Wälle, Lydia Zehnder and Muhammed Usman for support in the laboratories. We thank Franz Neubauer and Dejan Prelević for careful and helpful reviews.

\section{REFERENCES}

Anders, B., T. Reischmann, U. Poller and D. Kostopoulos (2005). Age and origin of granitic rocks of the eastern Vardar Zone, Greece: new constraints on the evolution of the Internal Hellenides. Journal of the Geological Society 162(5): 857-870.

Balintoni, I. (1994). Structure of the Apuseni Mountains. Romanian Journal of Tectonics and Regional Geology ALCAPA II field guidebook "South Carpathians and Apuseni Mountains"(75): 37-58.

Balintoni, I., C. Balica, M. N. Ducea, F. K. Chen, H. P. Hann and V. Sabliovschi (2009). Late CambrianEarly Ordovician Gondwanan terranes in the Romanian Carpathians: A zircon U-Pb provenance study. Gondwana Research 16(1): 119-133.

Balintoni, I., C. Balica, M. N. Ducea, L. Zaharia, F. K. Chen, M. Cliveti, H. P. Hann, L. Q. Li and L. Ghergari (2010). Late Cambrian-Ordovician northeastern Gondwanan terranes in the basement of the Apuseni Mountains, Romania. Journal of the Geological Society 167(6): 1131-1145.

Bernoulli, D. and H. Laubscher (1972). The palinspastic problem of the Hellenides. Eclogae Geologicae Helvetiae 65(1): 107.

Berza, T., E. Constantinescu and S. N. Vlad (1998). Upper Cretaceous Magmatic Series and Associated Mineralisation in the Carpathian - Balkan Orogen. Resource Geology 48(4): 291-306.

Bonev, N., P. Marchev, R. Moritz and P. Filipov (2015). Timing of igneous accretion, composition, and temporal relation of the Kassandra-Sithonia rift-spreading center within the eastern Vardar suture 
zone, Northern Greece: insights into Jurassic arc/back-arc systems evolution at the Eurasian plate margin. International Journal of Earth Sciences 104(7): 1837-1864.

Borojević Šoštarić, S., A. L. Palinkaš, F. Neubauer, V. Cvetković, M. Bernroider and J. Genser (2014). The origin and age of the metamorphic sole from the Rogozna Mts., Western Vardar Belt: New evidence for the one-ocean model for the Balkan ophiolites. Lithos 192-195: 39-55.

Bortolotti, V., M. Chiari, M. Marroni, L. Pandolfi, G. Principi and E. Saccani (2013). Geodynamic evolution of ophiolites from Albania and Greece (Dinaric-Hellenic belt): one, two, or more oceanic basins? International Journal of Earth Sciences 102(3): 783-811.

Bortolotti, V., M. Marroni, I. Nicolae, L. Pandolfi, G. Principi and E. Saccani (2002). Geodynamic Implications of Jurassic Ophiolites Associated with Island-Arc Volcanics, South Apuseni Mountains, Western Romania. International Geology Review 44(10): 938 - 955.

Bortolotti, V., M. Marroni, I. Nicolae, L. Pandolfi, G. Principi and E. Saccani (2004). An update of the Jurassic ophiolites and associated calc-alkaline rocks in the South Apuseni Mountains (western Romania). Ofioliti 29(1): 5-18.

Bortolotti, V. and G. Principi (2005). Tethyan ophiolites and Pangea break-up. Island Arc 14(4): 442470.

Božović, M., D. Prelević, R. L. Romer, M. Barth, P. Van Den Bogaard and B. Boev (2013). The Demir Kapija Ophiolite, Macedonia (FYROM): a Snapshot of Subduction Initiation within a Back-arc. Journal of Petrology 54(7): 1427-1453.

Bucur, I. and E. Săsăran (2005). Micropaleontological assemblages from the upper Jurassic-lower Cretaceous deposits of Trascău Mountains and their biostratigraphic significance. Acta Paleontologica Romaniae 5: 27-38.

Cohen, K., S. Finney, P. Gibbard and J.-X. Fan (2013). The ICS international chronostratigraphic chart. Episodes 36(3): 199-204.

Csontos, L. and A. Vörös (2004). Mesozoic plate tectonic reconstruction of the Carpathian region. Palaeogeography, Palaeoclimatology, Palaeoecology 210(1): 1-56.

Dallmeyer, R. D., D. I. Pana, F. Neubauer and P. Erdmer (1999). Tectonothermal evolution of the Apuseni Mountains, Romania: Resolution of Variscan versus alpine events with Ar-40/Ar-39 ages. Journal of Geology 107(3): 329-352.

Dilek, Y. and H. Furnes (2011). Ophiolite genesis and global tectonics: Geochemical and tectonic fingerprinting of ancient oceanic lithosphere. Geological Society of America Bulletin 123(3-4): 387411.

Elliott, T. (2003). Tracers of the slab. Geophysical Monograph Series 138: 23-45.

Floyd, P., M. Yaliniz and M. Goncuoglu (1998). Geochemistry and petrogenesis of intrusive and extrusive ophiolitic plagiogranites, Central Anatolian Crystalline Complex, Turkey. Lithos 42(3): 225241.

Fügenschuh, B. and S. M. Schmid (2005). Age and significance of core complex formation in a very curved orogen: Evidence from fission track studies in the South Carpathians (Romania). Tectonophysics 404(1-2): 33-53.

Gaggero, L., M. Marroni, L. Pandolfi and L. Buzzi (2009). Modelling of oceanic lithosphere obduction: constraints from the metamorphic sole of Mirdita ophiolites (Northern Albania). Ofioliti 34(1): 17-42. 
Gehrels, G. E., V. A. Valencia and J. Ruiz (2008). Enhanced precision, accuracy, efficiency, and spatial resolution of $\mathrm{U}-\mathrm{Pb}$ ages by laser ablation-multicollector-inductively coupled plasma-mass spectrometry. Geochemistry, Geophysics, Geosystems 9(3).

Gröger, H. R., M. Tischler, B. Fügenschuh and S. M. Schmid (2013). Thermal history of the Maramureş area (Northern Romania) constrained by zircon fission track analysis: Cretaceous metamorphism and Late Cretaceous to Paleocene exhumation. Geologica Carpathica 64(5): 383-398.

Haas, J. and C. Pero (2004). Mesozoic evolution of the Tisza Mega-unit. International Journal of Earth Sciences 93(2): 297-313.

Handy, M. R., S. M. Schmid, R. Bousquet, E. Kissling and D. Bernoulli (2010). Reconciling platetectonic reconstructions of Alpine Tethys with the geological-geophysical record of spreading and subduction in the Alps. Earth-Science Reviews 102(3-4): 121-158.

Hawkesworth, C. J., S. P. Turner, F. McDermott, D. W. Peate and P. van Calsteren (1997). U-Th Isotopes in Arc Magmas: Implications for Element Transfer from the Subducted Crust. Science 276(5312): 551-555.

Hoeck, V., C. Ionescu, I. Balintoni and F. Koller (2009). The Eastern Carpathians "ophiolites" (Romania): Remnants of a Triassic ocean. Lithos 108(1-4): 151-171.

lancu, V., T. Berza, A. Seghedi, I. Gheuca and H.-P. Hann (2005). Alpine polyphase tectonometamorphic evolution of the South Carpathians: A new overview. Tectonophysics 410(1-4): 337365.

Ionescu, C., V. Hoeck, C. Tomek, F. Koller, I. Balintoni and L. Beşuţiu (2009). New insights into the basement of the Transylvanian Depression (Romania). Lithos 108(1-4): 172-191.

Karamata, S. (2006). The geological development of the Balkan Peninsula related to the approach, collision and compression of Gondwanan and Eurasian units. Geological Society, London, Special Publications 260(1): 155-178.

Klötzli, S. U., G. Buda and T. Skiöld (2004). Zircon typology, geochronology and whole rock Sr-Nd isotope systematics of the Mecsek Mountain granitoids in the Tisia Terrane (Hungary). Mineralogy and Petrology 81(1): 113-134.

Koglin, N., D. Kostopoulos and T. Reischmann (2009). Geochemistry, petrogenesis and tectonic setting of the Samothraki mafic suite, NE Greece: Trace-element, isotopic and zircon age constraints. Tectonophysics 473(1-2): 53-68.

Koglin, N., T. Reischmann, D. Kostopoulos, D. Matukov and S. Sergeev (2007). Zircon SHRIMP ages and the origin of ophiolitic rocks from the NE Aegean region, Greece. Geophysical Research Abstracts 9(paper 06848).

Kounov, A. and S. M. Schmid (2013). Fission-track constraints on the thermal and tectonic evolution of the Apuseni Mountains (Romania). International Journal of Earth Sciences 102(1): 207-233.

Kukoč, D., Š. Goričan, A. Košir, M. Belak, J. Halamić and H. Hrvatović (2015). Middle Jurassic age of basalts and the post-obduction sedimentary sequence in the Guevgueli Ophiolite Complex (Republic of Macedonia). International Journal of Earth Sciences 104(2): 435-447. 
Ludwig, K. J. (2012). User's Manual for Isoplot 3.75 A Geochronological Toolkit for Microsoft Excel. Berkeley Geochronology Center Special Publication. Berkeley CA, Berkeley Geochronolgy Center. 5: 75 .

Lupu, H., S. Peltz, S. Bostinescu, E. Rosu, H. G. Kräutner, M. Horvath, M. Muresan, G. Muresan, T. Bandrabur, A. Popescu and I. Nicolae (1986). Harta Geologica scale 1:50000 sheet 89a Gurasada. Bucharest, Institutul de Geologie si Geofizica.

Lupu, M., E. Antonescu, E. Avram, P. Dumitrica and I. Nicolae (1995). Comments on the age of some ophiolites from the north Drocea Mts. Romanian Journal of Tectonics and Regional Geology 76: 2125.

Márton, E., M. Tischler, L. Csontos, B. Fügenschuh and S. Schmid (2007). The contact zone between the ALCAPA and Tisza-Dacia mega-tectonic units of Northern Romania in the light of new paleomagnetic data. Swiss Journal of Geosciences 100(1): 109-124.

Mattinson, J. M. (2005). Zircon U-Pb chemical abrasion ("CA-TIMS") method: Combined annealing and multi-step partial dissolution analysis for improved precision and accuracy of zircon ages. Chemical Geology 220(1-2): 47-66.

Meinhold, G., D. Kostopoulos, T. Reischmann, D. Frei and M. K. BouDagher-Fadel (2009). Geochemistry, provenance and stratigraphic age of metasedimentary rocks from the eastern Vardar suture zone, northern Greece. Palaeogeography, Palaeoclimatology, Palaeoecology 277(3-4): 199225.

Miyashiro, A. (1974). Volcanic rock series in island arcs and active continental margins. American Journal of Science 274(4): 321-355.

Nicolae, I. and E. Saccani (2003). Petrology and geochemistry of the late Jurassic calc-alkaline series associated to Middle Jurassic ophiolites in the South Apuseni Mountains (Romania). Schweizerische Mineralogische Und Petrographische Mitteilungen 83(1): 81-96.

Nicolae, I., M. Soroiu and G. M. Bonhomme (1992). Ages K-Ar de quelques ophiolites des Monts Apuseni du sud (Roumanie) et leur signification géologique. Géologie Alpine 68: 77-83.

Pamić, J., B. Tomljenović and D. Balen (2002). Geodynamic and petrogenetic evolution of Alpine ophiolites from the central and NW Dinarides: an overview. Lithos 65(1-2): 113-142.

Pana, D. I., L. M. Heaman, R. A. Creaser and P. Erdmer (2002). Pre-alpine crust in the Apuseni Mountains, Romania: Insights from Sm-Nd and U-Pb data. Journal of Geology 110(3): 341-354.

Paton, C., J. Hellstrom, B. Paul, J. Woodhead and J. Hergt (2011). Iolite: Freeware for the visualisation and processing of mass spectrometric data. Journal of Analytical Atomic Spectrometry 26(12): 25082518.

Paton, C., J. D. Woodhead, J. C. Hellstrom, J. M. Hergt, A. Greig and R. Maas (2010). Improved laser ablation U-Pb zircon geochronology through robust downhole fractionation correction. Geochemistry, Geophysics, Geosystems 11(3): Q0AA06.

Pătraşcu, S., M. Bleahu and C. Panaiotu (1990). Tectonic implications of paleomagnetic research into Upper Cretaceous magmatic rocks in the Apuseni Mountains, Romania. Tectonophysics 180(2-4): 309-322. 
Pătraşcu, S., C. Panaiotu, M. Seclaman and C. E. Panaiotu (1994). Timing of rotational motion of Apuseni Mountains (Romania)-Paleomagnetic data from Tertiary magmatic rocks Tectonophysics 233(3-4): 163-176.

Petrus, J. A. and B. S. Kamber (2012). VizualAge: A Novel Approach to Laser Ablation ICP-MS U-Pb Geochronology Data Reduction. Geostandards and Geoanalytical Research 36(3): 247-270.

Pin, C., D. Briot, C. Bassin and F. Poitrasson (1994). Concomitant separation of strontium and samarium-neodymium for isotopic analysis in silicate samples, based on specific extraction chromatography. Analytica Chimica Acta 298(2): 209-217.

Reiser, M. K. (2015). The tectonometamorphic evolution of the Apuseni Mountains during the Cretaceous. PhD, University of Innsbruck.

Reiser, M. K., R. Schuster, R. Spikings, P. Tropper and B. Fügenschuh (2016). From nappe stacking to exhumation: Cretaceous tectonics in the Apuseni Mountains (Romania). International Journal of Earth Sciences: 1-27.

Robertson, A., S. Karamata and K. Šarić (2009). Overview of ophiolites and related units in the Late Palaeozoic-Early Cenozoic magmatic and tectonic development of Tethys in the northern part of the Balkan region. Lithos 108(1-4): 1-36.

Rollinson, H. (2009). New models for the genesis of plagiogranites in the Oman ophiolite. Lithos 112(3): 603-614.

Rosu, E., I. Seghedi, H. Downes, D. H. M. Alderton, A. Szakacs, Z. Pecskay, C. Panaiotu, C. E. Panaiotu and L. Nedelcu (2004). Extension-related Miocene calc-alkaline magmatism in the Apuseni Mountains, Romania: Origin of magmas. Schweizerische Mineralogische Und Petrographische Mitteilungen 84(1-2): 153-172.

Rudnick, R. L. and S. Gao (2014). 4.1 - Composition of the Continental Crust. Treatise on Geochemistry (Second Edition). H. D. H. K. Turekian. Oxford, Elsevier: 1-51.

Saccani, E., I. Nicolae and R. Tassinari (2001). Tectono-magmatic setting of the Jurassic ophiolites from the Soth Apuseni Mountains (Romania): petrological and geochemical evidence. Ofioliti 26: 922.

Săndulescu, M. (1984). Geotectonica României. Bucharest, Editura Tehnică.

Săndulescu, M. (1994). Overview on Romanian Geology. 2. Alcapa Congress Field Guidebook. Romanian Journal of Tectonics and Regional Geology 75(Suppl. 2): 3-15.

Šarić, K., V. Cvetković, R. L. Romer, G. Christofides and A. Koroneos (2009). Granitoids associated with East Vardar ophiolites (Serbia, F.Y.R. of Macedonia and northern Greece): Origin, evolution and geodynamic significance inferred from major and trace element data and $\mathrm{Sr}-\mathrm{Nd}-\mathrm{Pb}$ isotopes. Lithos 108(1-4): 131-150.

Savu, H. (1996). A comparative study of the ophiolites obducted from two different segments of the Mures ocean "Normal"median ridge (Romania). Romanian Journal of Petrology 77: 46-60.

Savu, H., I. Berlbeleac, A. Stefan and F. Papaianopol (1979a). Harta Geologica scale 1:50000 sheet 73a Halmagiu. Bucharest, Institutul de Geologie si Geofizica. 
Savu, H., M. Lupu, E. Avram and F. Marinescu (1979b). Harta Geologica scale 1:50000 sheet 72c Săvârşin. Bucharest, Institutul de Geologie si Geofizica.

Savu, H., M. Lupu, D. Lupu, A. Stefan and G. Istrate (1979c). Harta Geologica scale 1:50000 sheet 72d Rosia Noua. Bucharest, Institutul de Geologie si Geofizica.

Savu, H., F. Marinescu, E. Rosu, I. Nicolae, M. Muresan and A. Popescu (1991). Harta Geologica scale 1:50000 sheet 88b Lapugi-Costei. Bucharest, Institutul de Geologie si Geofizica.

Savu, H., C. Udrescu and V. Neacsu (1981). Geochemistry and geotectonic setting of ophiolites and island arc volcanics in the Mures zone (Romania). Ofioliti 6(2-3): 269-286.

Schmid, S. M., D. Bernoulli, B. Fügenschuh, L. Matenco, S. Schefer, R. Schuster, M. Tischler and K. Ustaszewski (2008). The Alpine-Carpathian-Dinaridic orogenic system: correlation and evolution of tectonic units. Swiss Journal of Geosciences 101(1): 139-183.

Schuller, V., W. Frisch, M. Danisik, I. Dunkl and M. C. Melinte (2009). Upper Cretaceous Gosau deposits of the Apuseni Mountains (Romania) - Similarities and differences to the Eastern Alps. Austrian Journal of Earth Sciences 102(1).

Searle, M. and J. Cox (1999). Tectonic setting, origin, and obduction of the Oman ophiolite. Geological Society of America Bulletin 111(1): 104-122.

Seghedi, I., H. Downes, A. Szakács, P. R. D. Mason, M. F. Thirlwall, E. Roşu, Z. Pécskay, E. Márton and C. Panaiotu (2004). Neogene-Quaternary magmatism and geodynamics in the Carpathian-Pannonian region: a synthesis. Lithos 72(3-4): 117-146.

Şerban, D., I. Bucur and E. Săsăran (2004). Micropaleontological assemblages and microfacies characteristics of the Upper Jurassic limestones from Căprioara-Pojoga (Mureş trough). Acta Paleontologica Romaniae 4: 475-484.

Stracke, A., A. W. Hofmann and S. R. Hart (2005). FOZO, HIMU, and the rest of the mantle zoo. Geochemistry Geophysics Geosystems 6.

Sun, S.-s. and W. F. McDonough (1989). Chemical and isotopic systematics of oceanic basalts: implications for mantle composition and processes. Geological Society, London, Special Publications 42(1): 313-345.

Turpaud, P. (2006). Characterization of igneous terranes by zircon dating: implications for the UHP relicts occurrences and suture identification in the Central Rhodope, Northern Greece, Johannes Gutenberg-Universität.

Ustaszewski, K., A. Kounov, S. M. Schmid, U. Schaltegger, E. Krenn, W. Frank and B. Fugenschuh (2010). Evolution of the Adria-Europe plate boundary in the northern Dinarides: From continentcontinent collision to back-arc extension. Tectonics 29.

Ustaszewski, K., S. M. Schmid, B. Fügenschuh, M. Tischler, E. Kissling and W. Spakman (2008). A mapview restoration of the Alpine-Carpathian-Dinaridic system for the Early Miocene. Swiss Journal of Geosciences 101(0): 273-294.

von Quadt, A., D. Gallhofer, M. Guillong, I. Peytcheva, M. Waelle and S. Sakata (2014). U-Pb dating of CA/non-CA treated zircons obtained by LA-ICP-MS and CA-TIMS techniques: impact for their geological interpretation. Journal of Analytical Atomic Spectrometry 29(9): 1618-1629. 
Woodhead, J. D., J. M. Hergt, J. P. Davidson and S. M. Eggins (2001). Hafnium isotope evidence for 'conservative' element mobility during subduction zone processes. Earth and Planetary Science Letters 192(3): 331-346.

Zachariadis, P. T. (2007). Ophiolites of the eastern Vardar Zone, N. Greece. PhD PhD, Johannes Gutenberg-Universität, Mainz.

Zacher, W. and M. Lupu (1999). Pitfalls on the race for an ultimate Tethys model. International Journal of Earth Sciences 88(1): 111-115.

Zimmerman, A., H. Stein, J. Hannah, D. Koželj, K. Bogdanov and T. Berza (2008). Tectonic configuration of the Apuseni-Banat-Timok-Srednogorie belt, Balkans-South Carpathians, constrained by high precision Re-Os molybdenite ages. Mineralium Deposita 43(1): 1-21. 


\section{Online Resource 1:}
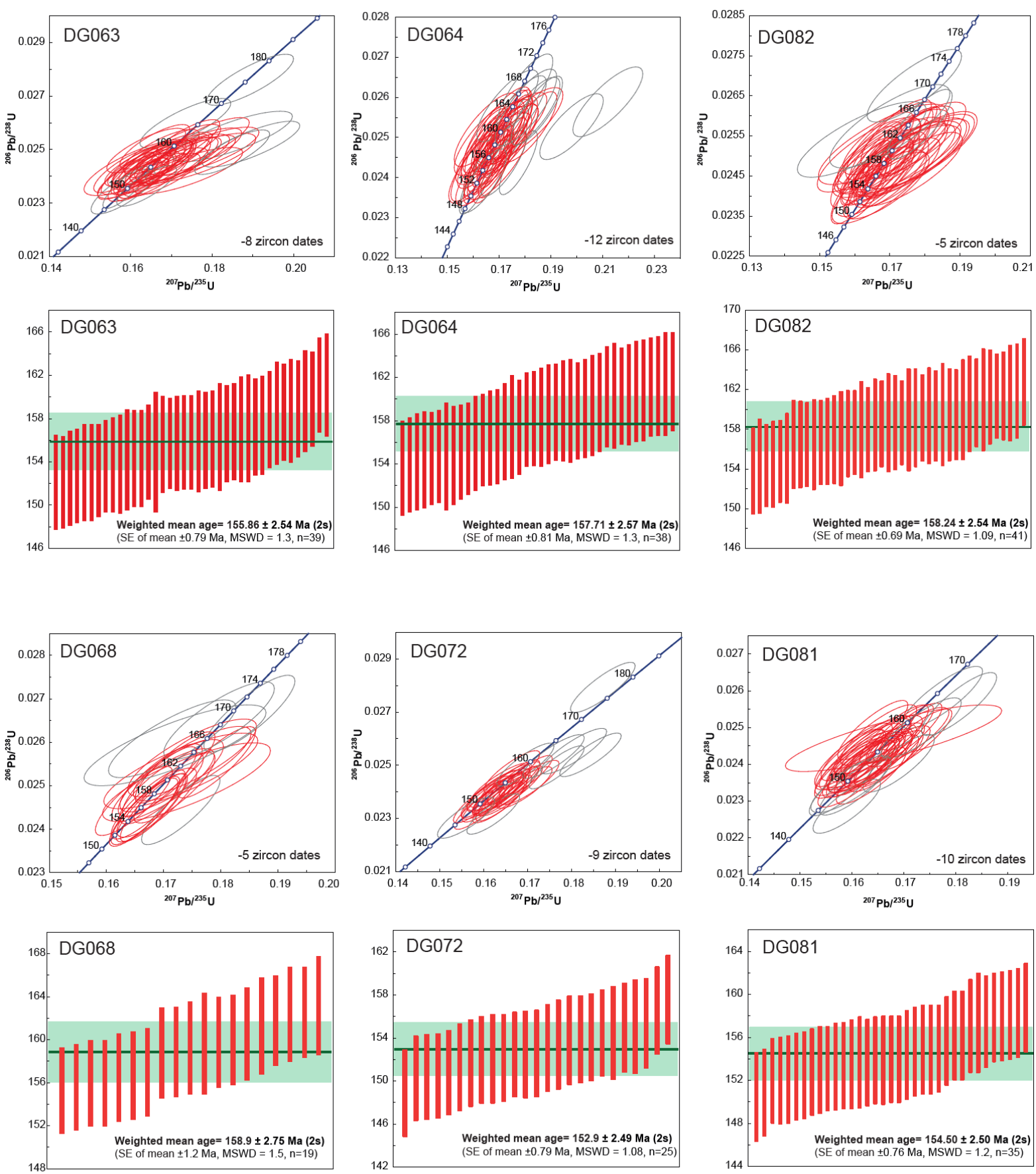

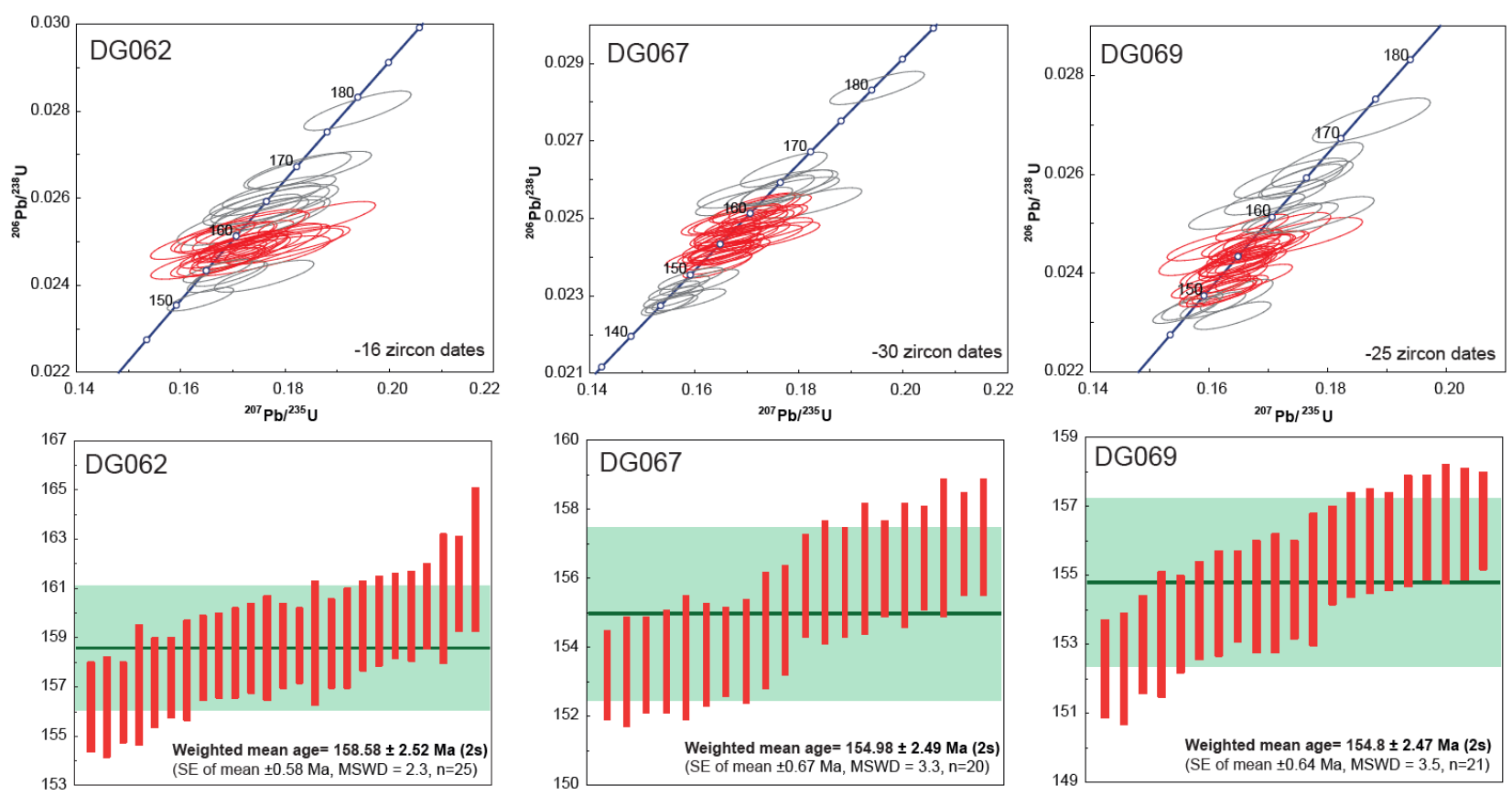